\title{
ANÁLISE ESPECTROFOTOMÉTRICA DA FRAÇÃO LIPÍDICA DE GRÃOS DE SOJA [Glycine max (L.) Merrill] MACERADOS
}

\section{CARLOS MAGNO EVANGELISTA \\ Engenheiro Químico}

Orientadora: Prof. Dr ${ }^{\mathrm{a}}$. MARISA A. B. REGITANO-D'ARCE

Dissertação apresentada à Escola Superior de Agricultura "Luiz de Queiroz", da Universidade de São Paulo, para obtenção do título de Mestre em Ciências, Área de Concentração: Ciência e Tecnologia de Alimentos.

PIRACICABA

Estado de São Paulo - Brasil

Outubro - 1996 
Evangelista, Carlos Magno

Análise espectrofotométrica da fraçāo lipídica de grãos de soja [Glycine max (L.) Merrill] macerados / Carlos Magno Evangelista. - - Piracicaba , 1996.

70p. : il.

Dissertação (mestrado) - - Escola Superior de Agricultura Luiz de Queiroz, 1996.

Bibliografia.

1. Espectrofotometria 2. Lipídio de soja - Oxidação enzimática - Análise 3. Lipoxigenase de soja 4. Soja - Atividade enzimática 5. Soja - Grão - Maceração I. Título

CDD 664.726 


\section{ANÁLISE ESPECTROFOTOMÉTRICA DA FRAÇĀO LIPÍDICA DE GRÃOS DE SOJA [Glycine max (L.) Merrill] MACERADOS}

CARLOS MAGNO EVANGELISTA

Aprovado em 12.12.1996

Comissão Julgadora:

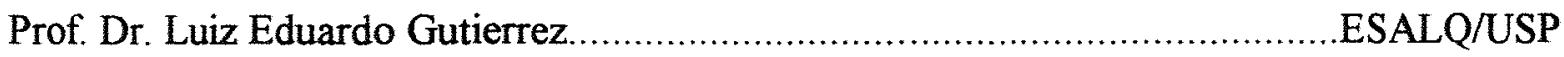
Prof. Dr. Murilo de Melo..................................................................ERTEC/ESALQ/USP Prof. Dr ${ }^{\mathrm{a}}$. Marisa Aparecida Bismara Regitano d'Arce ......................................SALQ/USP

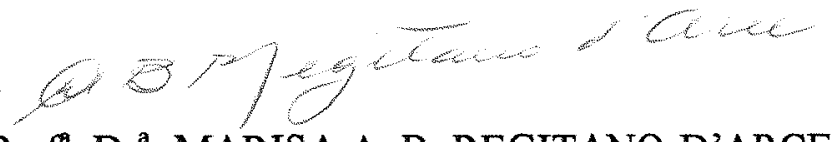

Prof ${ }^{\mathrm{a}}$. Dr ${ }^{\mathrm{a}}$. MARISA A. B. REGITANO-D'ARCE Orientadora 


\section{AGRADECIMENTOS}

À Professora $\mathrm{Dr}^{\mathrm{a}}$. Marisa A. B. Regitano d'Arce, pela orientação, amizade, dedicação, confiança e apoio que muito contribuíram para a realização deste trabalho.

Ao Professor Dr. César Gonçalves de Lima, do Departamento de Ciências Básicas da Faculdade de Zootecnia e Engenharia de Alimentos da Universidade de São Paulo, campus de Pirassununga - SP, pela assessoria na análise estatística dos resultados experimentais.

Ao Pesquisador José Renato Bordingnon do Centro Nacional de Pesquisa de Soja (CNPSo) da Empresa Brasileira de Pesquisa Agropecuária (EMBRAPA) de Londrina - PR, pelo fornecimento do cultivar de soja Davies utilizado neste trabalho.

Ao Professor Dr. Antonio Joaquim de Oliveira do Laboratório de Laticínios do Departamento de Ciência e Tecnologia Agroindustrial da ESALQ/USP, pela colaboração no uso do liofilizador.

Aos meus pais e irmãos pelo incentivo e apoio à realização deste trabalho.

A Cecilia Lamontagna pela paciência, carinho e companhia.

Às amigas Érika M. R. Gutierrez, Fabiana M. de Siqueira, Mariana Micotti da Glória, Maria F. A. Prado e Silvia M. F. Carpi pela amizade e ajudas no Laboratório de Elaiotecnia.

Ao Conselho Nacional de Desenvolvimento Científico e Tecnológico ( $\mathrm{CNPq}$ ) pela bolsa de Mestrado.

A todas as pessoas que, direta ou indiretamente, colaboraram para a realização deste trabalho. 
4.2.1. Análises de caracterização dos grãos.

4.2.2. Tratamentos - condições de maceração.

4.2.3. Extração da fração lipídica.

4.2.4. Análise espectrofotométrica da fração lipídica.

4.2.5. Análise estatística.

5.1. Características do cultivar estudado.

5.1.1. Composição química dos grãos.

5.1.2. Análise da fração lipídica extraída...

5.1.3. Absorção de água nas macerações.

5.2. Extração da fração lipídica.

5.3. Características espectrofotométricas da fração lipídica. 
5.4. Efeito dos tratamentos na fração lipídica.

5.4.1. Grãos íntegros macerados em diferentes temperaturas...

5.4.2. Grãos integros aquecidos em forno de microondas e macerados

5.4.3. Grãos íntegros macerados em diferentes soluções.

5.4.4. Grãos triturados e adicionados de diferentes soluções.

6. CONCLUSÕES 


\section{LISTA DE FIGURAS}

Página

Figura 1. Representação da oxidação do ácido linoléico pela lipoxigenase formando 9S- e 13S- hidroperóxidos.

05

Figura 2. Curvas de absorção de água pelo cultivar Davies em várias temperaturas.

Figura 3. Leituras de absorbância em $232 \mathrm{~nm}$ em função da concentração de óleo

Figura 4. Coeficientes de extinção da fração lipídica de grãos macerados em água em diferentes temperaturas e liofilizados.

Figura 5. Curva de aquecimento de grãos de soja em forno de microondas

Figura 6. Perda de água de grãos aquecidos em forno de microondas

Figura 7. Coeficiente de extinção da fração lipídica de grãos aquecidos em forno de microondas, macerados em água e liofilizados.

Figura 8. Coeficiente de extinção da fração lipídica de grãos íntegros macerados em diversas soluções e liofilizados.

Figura 9. Coeficientes de extinção da fração lipídica de grãos triturados e adicionados de diversas soluções. 


\section{LISTA DE TABELAS}

Página

Tabela 1. Composição química dos grãos de soja do cultivar Davies

Tabela 2. Coeficiente de extinção e índices de acidez (I.A.) e de peróxido (I.P.) do óleo extraído (óleo bruto) do cultivar Davies

Tabela 3. Alteração das características físicas dos grãos na maceração (pernoite à temperatura ambiente).

Tabela 4. Comparação da eficiência dos métodos de extração

Tabela 5. Coeficientes de extinção da fração lipídica em função do solvente utilizado para medida da absorbância.

Tabela 6. Energia mínima absorvida (MEA) pelos grãos de soja no aquecimento em forno de microondas

Tabela 7. Absorbâncias das soluções de maceração em relação à água destilada 


\section{ANÁLISE ESPECTROFOTOMÉTRICA DA FRAÇÃO LIPÍdICA DE GRÃOS DE SOJA [Glycine max (L.) Merrill] MACERADOS}

Autor: CARLOS MAGNO EVANGELISTA Orientadora: Prof ${ }^{\mathrm{a}}$. Dr ${ }^{\mathrm{a}}$. MARISA A. B. REGITANO-D'ARCE

\section{RESUMO}

O "off-flavor" dos derivados de soja, particularmente do extrato hidrossolúvel ("leite de soja"), é um dos principais obstáculos a sua aceitação pelos ocidentais. A origem desse "flavor" está, pelo menos parcialmente, na oxidação de ácidos graxos catalisada pelas isoenzimas lipoxigenases quando os tecidos dos grãos sofrem danos na presença de água. Já na maceração dos grãos, no processo tradicional de produção de leite de soja, células do cotilédone sofrem rupturas devido à rápida absorção de água permitindo o contato enzima-substrato. $O$ objetivo do presente trabalho foi a extração e análise espectrofotométrica em $232 \mathrm{~nm}$ da fração lipídica de grãos macerados em diferentes condições, e depois liofilizados, para a avaliação do nivel de oxidação sofrido. Para tanto, adaptou-se o método de extração de lipídeos de tecidos de organismos vivos que se baseia no uso de mistura de solventes polares e apolares e é simples, rápido e eficiente. Este método permitiu ainda o uso direto da espectrofotometria para a análise da fração lipídica (determinação de dienos conjugados pelo cálculo do coeficiente de extinção), possibilitando verificar a ocorrência de oxidação em várias condições de maceração. 
Verificou-se que quanto maior a temperatura de maceração, menor o tempo necessário e menor a oxidação sofrida pela fração lipídica dos grãos e que, quanto maior o tempo de aquecimento dos grãos em forno de microondas, menor a ocorrência de oxidação durante a maceração. Os coeficientes de extinção destes dois tratamentos puderam ser expressos por equações polinomiais de $2^{\underline{a}}$ ordem, em função da temperatura de maceração e do tempo de aquecimento no forno de microondas, respectivamente.

A maceração de grãos nas várias soluções testadas de $\mathrm{NaOH} 0,05 \mathrm{~N}$, $\mathrm{NaHCO}_{3} 0,5 \%$, Etanol $15 \%(\mathrm{v} / \mathrm{v}), \mathrm{HCl} 0,30 \mathrm{M} \mathrm{e} \mathrm{Cu}^{2+} 12 \mathrm{ppm}$, não impediu a oxidação da fração lipídica. 


\title{
SPECTROPHOTOMETRIC ANALYSIS OF THE LIPIDIC FRACTION IN SOAKED SOYBEANS [Glycine $\max ($ L.) Merrill]
}

\author{
Author: CARLOS MAGNO EVANGELISTA \\ Adviser: Prof ${ }^{\mathrm{a}}$. Dr ${ }^{\mathrm{a}}$. MARISA A. B. REGITANO-D'ARCE
}

\section{SUMMARY}

The flavor of the soybeans products, particularly of the aqueous extract (soymilk), is one of the main problems to its acceptance by Occidental people. The compounds responsible for this flavor are, at least partially, secondary products of the oxidation of the fatty acids catalyzed by a group of isoenzymes called lipoxygenases when raw tissues of the soybean cotyledons are damaged or broken and exposed to moisture. During soaking of soybean in the traditional procedure of soymilk preparation, cells of the cotyledons are broken due to the rapid water uptake. The aim of this research was the extraction and spectrophotometric analysis at $232 \mathrm{~nm}$ of the lipidic fraction of soybeans soaked under different conditions and then freeze-dried. A method of extraction of lipids from biological matrices with mixtures of polar and apolar solvents, that is accurate, rapid, and simple, was used. It was possible to analyse directly the lipidic fraction and detect the oxidation under several conditions of soaking. The results showed that the extinction coefficients of soybean lipidic fraction decreased with increasing soaking temperature and microwave heating time and that can be represented by second order polinomial equations. Soaking soybeans in different aqueous solutions $\left[\mathrm{NaOH} 0.05 \mathrm{~N}, \mathrm{NaHCO}_{3} 0.5 \%\right.$, Ethanol 
$15 \%(\mathrm{v} / \mathrm{v}), \mathrm{HCl} 0.30 \mathrm{M}$ and $\left.\mathrm{Cu}^{2+} 12 \mathrm{ppm}\right] \mathrm{did}$ not prevent the oxidation of the lipidic fraction. 


\section{INTRODUÇÃO}

A soja [Glycine max (L.) Merrill] é o único vegetal cultivado em larga escala cuja proteína substitui a contento a de origem animal, e ainda, constitui a proteina de mais baixo custo que se conhece. Ela produz mais proteínas por hectare que qualquer outra cultura agrícola. Disso se deduz sua importância. Mas sua qualidade, como a de qualquer outro alimento, é julgada não só por seu valor nutricional, como também por sua cor, textura e "flavor". Justamente, um dos principais obstáculos ao uso da soja como fonte de proteína para consumo humano nos países do ocidente é seu "flavor" (sabor e odor) característico. Este tem sido definido como amargo, adstringente, rançoso, de tinta ou de feijão cru. Análises do leite de soja levaram à identificação de 41 compostos responsáveis por esse efeito. Tem-se evidenciado que tais compostos (principalmente cetonas, aldeídos e hidrocarbonetos) são produtos secundários de oxidações enzimáticas de ácidos graxos insaturados presentes nos lipídeos catalisadas por um conjunto de enzimas (isozimas ou isoenzimas) denominadas lipoxigenases (LOX ou simplesmente L). Assim, a qualidade dos grãos de soja e/ou seus derivados está diretamente relacionada principalmente com o nivel de oxidação (mas também com o de hidrólise) sofrido pela fração lipídica dos grãos. As sementes de soja constituem uma fonte rica de LOX e de 
seus substratos, os ácidos linoléico e linolênico. As lipoxigenases podem representar até $2 \%$ do total de proteínas contidas no grão de soja. Já se demonstrou porém, que os grãos inteiros de soja, em que as enzimas lipoxigenases estão separadas dos substratos (ácidos graxos), não contém os compostos responsáveis pelo mau sabor. A enzima só é exposta ao substrato quando os tecidos do cotilédone se quebram ou se danificam durante a colheita, o transporte ou o armazenamento. Mas, mesmo nesses casos, a enzima permanece praticamente inativa enquanto os grãos se mantém secos. Altas umidades e temperaturas são condições ideais para a interação ocorrer. Também no processamento da soja é freqüente, embora evitável, a quebra dos grãos e sua exposição à umidade piora o sabor dos produtos da leguminosa. Particularmente no processo tradicional de obtenção do extrato hidrossolúvel (leite de soja), ela é macerada em água por várias horas e depois triturada, permitindo a ocorrência da oxidação. Portanto, a etapa de maceração seguida da trituração no processo de produção de leite de soja constituem as fases críticas, origens da formação dos produtos indesejados que possuem limites de percepção (valores de "threshold") muito baixos. 


\section{OBJETIVOS}

Pretendeu-se verificar o nível de oxidação enzimática (devido à ação das LOX) sofrido pela fração lipidica de grãos de soja submetidos à maceração em diferentes condições, a partir da análise direta da fração lipídica, o que equivale a verificar o efeito da ação das lipoxigenases. Para isso, buscou-se a adaptação de métodos rápidos e eficazes de extração e análise da fração lipídica de modo que um número grande de condições de maceração pudessem ser testadas. Foram realizadas macerações de grãos íntegros em água a várias temperaturas, em diversas soluções aquosas (ácidas, básicas, etc.) à temperatura ambiente e, em água à temperatura ambiente de grãos previamente aquecidos em forno de microondas por vários períodos de tempo. Também analisou-se a fração lipídica de grãos triturados e adicionados de água e das várias soluções aquosas testadas com grãos íntegros. Após a maceração e os grãos terem sido liofilizados, a fração lipídica foi extraída e a seguir, analisada por método espectrofotométrico. 


\section{REVISÃO DA LITERATURA}

As lipoxigenases constituem um importante fator na geração, a partir de lipídeos, dos compostos responsáveis pelo "flavor" desagradável quando grãos de soja são processados sob condições de alta umidade como na preparação de leite de soja pelo processo tradicional (Wolf, 1975). São importantes no desenvolvimento do "flavor" característico de muitos frutos e vegetais de forma benéfica, mas também, na deterioração da qualidade de alguns alimentos e na geração de "flavors" desagradáveis em outros, particularmente em sementes leguminosas tais como soja, ervilha, lentilha, etc (Rackis et al.,1979).

\subsection{As isoenzimas lipoxigenases ( $L O X$ ou $L$ )}

As lipoxigenases (linoleato : oxigênio oxidoredutase, EC 1.13.11.12) são isoenzimas que catalisam a incorporação de moléculas de oxigênio em ácidos graxos polinsaturados que possuem a estrutura cis,cis-1,4-pentadieno. Pela incorporação do oxigênio molecular, o principal produto formado é hidroperóxido na posição $C_{9}$ ou $C_{13}$ dependendo da origem da enzima ou do $\mathrm{pH}$ da reação. Os ácidos graxos vegetais mais 
comuns que possuem a estrutura cis,cis-1,4-pentadieno são os ácidos linoléico e linolênico (Vick \& Zimmerman, 1987). A reação enzimática, representada na Figura 1 para o ácido linoléico, pode ser acompanhada observando-se o aumento da absorção de luz em $234 \mathrm{~nm}$ devido à formação de ligações duplas conjugadas (dienos conjugados) ou medindo-se o consumo de oxigênio com o auxilio de eletrodos de $\mathrm{O}_{2}$ (Axelrod et al., 1981).

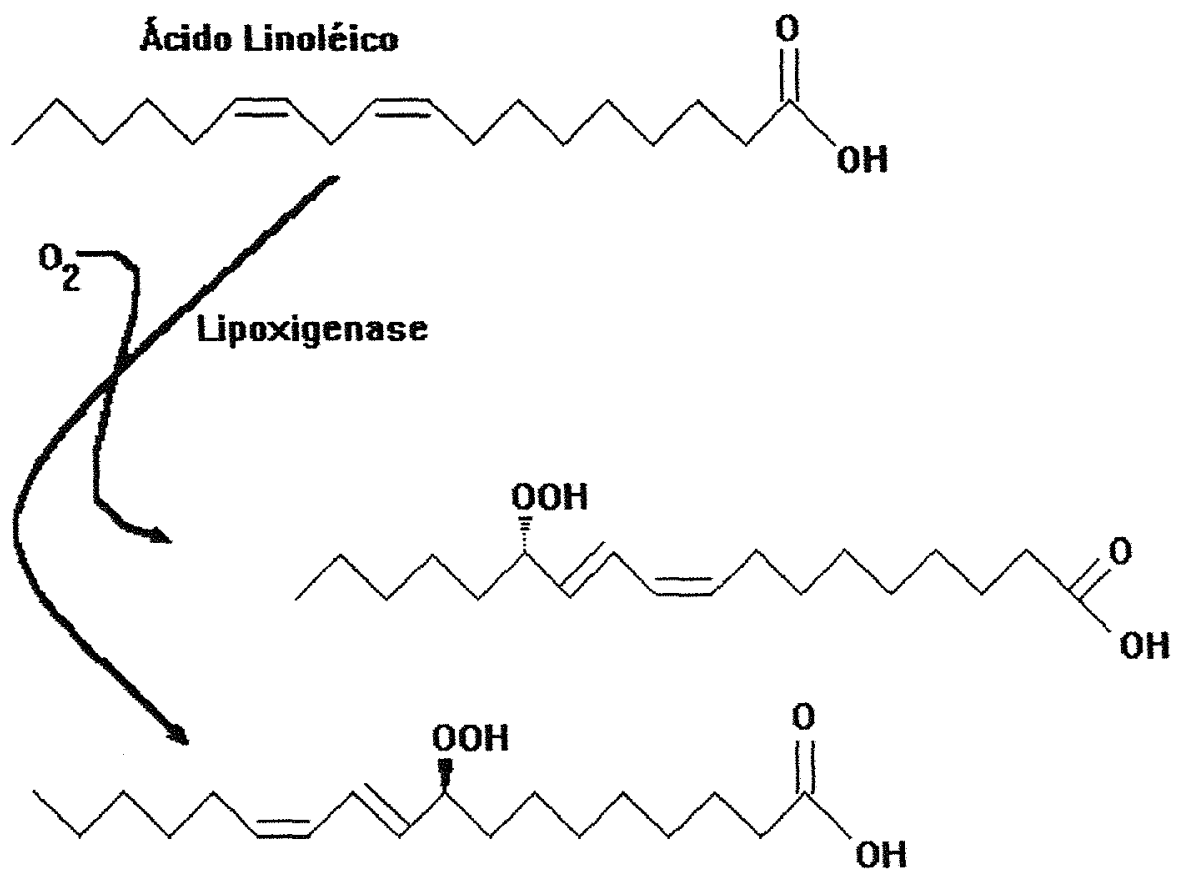

Figura 1 - Representação da oxidação do ácido linoléico pela lipoxigenase formando 9S- e 13Shidroperóxidos.

Fonte: Gardner, 1989. 
No método espectrofotométrico, a unidade de atividade da lipoxigenase (U) é definida como sendo a quantidade de enzima (em $\mathrm{mg}$ ) capaz de produzir uma variação na densidade ótica $(\Delta D O)$ de 0,001 unidade por minuto, nas condições do ensaio (Barros et al., 1984).

As lipoxigenases são encontradas numa ampla variedade de organismos incluindo mais de 60 espécies de plantas superiores, algas eucariotas, leveduras de panificação e outros fungos e uma cianobactéria (Siedow, 1991).

Todas as isoenzimas são globulares, solúveis em água e consistem de um polipeptídeo simples com um peso molecular em torno de 96.000 (Siedow, 1991). Cada isoenzima contém, por molécula, um átomo de ferro não hêmico ligado covalentemente à cadeia protéica da enzima que se alterna entre os estados de oxidação $\mathrm{Fe}^{2+}$ e $\mathrm{Fe}^{3+}$ durante a catálise, sendo portanto essencial a sua ação catalítica (Vick $\varepsilon$ Zimmerman, 1987).

Os grãos de soja constituem a fonte mais rica de lipoxigenases, sendo que quatro isoenzimas foram isoladas, as lipoxigenases L-1, L-2, L-3a e L-3b. Estas isoenzimas diferem entre si em vários aspectos bioquímicos tais como $\mathrm{pH}$ ótimo de ação, especificidade para substrato, regio-especificidade, produtos primários e secundários formados e valor de $\mathrm{K}_{\mathrm{m}}$. As isoenzimas $\mathrm{L}-3 \mathrm{a}$ e $\mathrm{L}-3 \mathrm{~b}$ são muito similares em suas propriedades e, para fins analíticos, podem ser consideradas idênticas (Axelrod et al., 1981). 
As lipoxigenases L-1 e L-2 de sementes de soja em germinação foram localizadas no citoplasma de todas as células do cotilédone, mas não em mitocôndrios, glioxissomos, corpos protéicos, corpos lipídicos ou outras organelas (Song et al., 1990).

\subsection{Condições para atuação das lipoxigenases}

Diversos pesquisadores contribuiram para evidenciar as condições em que as lipoxigenases atuam na oxidação lipídica.

Wilkens et al. (1967) determinaram que a rápida formação (quase instantânea) do "flavor" oxidado durante a trituração de grãos de soja com água é devido à oxidação de lípideos polinsaturados catalisada por lipoxidases (nome dado às lipoxigenases na época).

Segundo Nelson et al. (1976), quando o tecido do cotilédone do grão de soja é danificado ou rompido, a enzima lipoxigenase bem como o substrato lipídico são liberados. Enquanto o tecido estiver seco (aproximadamente 13\% de umidade) a enzima não catalisa a oxidação do substrato. Entretanto, se água é adicionada a temperaturas abaixo daquela em que estas enzimas são inativadas, a reação ocorre rapidamente e produz "odor de feijão" ou "sabor de oxidado", altamente rejeitáveis, exceto aos orientais que desenvolveram paladar tolerante a eles.

Robertson et al. (1973) analisaram grãos com diferentes níveis de dano no campo e no armazém para determinar a qualidade do óleo, e verificaram aumento da acidez, da cor Lovibond e do conteúdo de produtos de deterioração oxidativa do óleo em 
função da extensão dos danos. Segundo Baker et al. (1973), o tratamento térmico dos grãos de soja antes da extração aumenta a estabilidade do óleo, presumivelmente, pela inativação das enzimas oxidativas dos lipídeos, como as lipoxigenases, mas concorre para a redução da solubilidade da proteína e consequentemente, do rendimento na sua extração.

Gardner (1979) também enfatizou a importância da ruptura dos tecidos para a iniciação da peroxidação lipídica. Este mesmo autor (Gardner, 1975) já afirmara que em muitas plantas a presença de lipoxigenase parecia predeterminar a formação de hidroperóxidos, especialmente se a integridade celular fosse mecanicamente rompida.

A primeira e mais importante etapa nos processos tradicionais para se preparar alimentos de soja no oriente é a maceração dos grãos secos que, se acredita, reduz o tempo de cozimento e melhora a qualidade do produto, embora não esteja claro se esta melhoria diz respeito ao valor nutricional, à textura ou ao flavor (Wang et al., 1979).

Wilkens et al. (1967) demonstraram que se grãos de soja são triturados com água a temperaturas entre 80 e $100{ }^{\circ} \mathrm{C}$, a formação dos produtos responsáveis pelo "flavor" desagradável é quase que completamente impedida resultando num leite de soja organolépticamente melhor. Porém, Badenhop \& Wilkens (1969) verificaram que, quando a trituração a altas temperaturas é precedida por uma maceração inicial, uma significativa quantidade do composto 1-octen-3-ol é formado, dependendo de várias condições ambientes, inclusive do pH. Segundo Frankel (1985), este é, justamente, o composto volátil mais potente (embora não seja o de maior concentração, seu limite de 
percepção é de $0,0075 \mathrm{ppm}$ ) dentre os produtos responsáveis pela formação do "flavor" de oxidado oriundos da autooxidação de óleo de soja. Portanto, a oxidação da fração lipidica dos grãos de soja deve ocorrer já no processo de maceração, antes mesmo da trituração dos grãos.

Segundo Bewley \& Black (1994), durante a germinação de sementes, se a absorção de água for muito rápida, elas podem sofrer danos (rupturas) e liberar nutrientes para o solo estimulando o crescimento de fungos e bactérias que podem invadílas e deteriorá-las. Há liberação de gases adsorvidos em colóides e perdas para o meio externo de solutos tais como açúcares, ácidos orgânicos, íons, aminoácidos e proteínas. Grãos de soja também perdem certos inibidores de proteinases e lectinas de sua parede celular no início da embebição e estes compostos seriam agentes protetores contra microrganismos ou insetos invasores. Wang et al. (1979) estudaram as alterações bem como os efeitos que ocorrem em várias condições de hidratação de grãos de soja e concluíram que sólidos solúveis são lixiviados dos grãos em proporções razoavelmente constantes durante toda a hidratação, e as quantidades lixiviadas são maiores às temperaturas mais elevadas. A temperatura é o fator mais importante na velocidade de absorção de água e na perda de sólidos. Do total de sólidos perdidos (que chega a 10,4\% após $24 \mathrm{~h} / 37^{\circ} \mathrm{C}$ ), 7 a $16 \%$ são proteínas em macerações de $2 \mathrm{~h} / 20^{\circ} \mathrm{C}$ e, de $24 \mathrm{~h} /$ $37^{\circ} \mathrm{C}$, respectivamente. A proporção de proteína perdida aumenta com o aumento do tempo e da temperatura de hidratação.

Assim, seria razoável considerar que, também as lipoxigenases, que se encontram no citoplasma das células dos cotilédones, conforme Song et al. (1990), sejam 
liberadas na maceração, podendo entrar em contato com os corpos lipídicos e atuar na catálise da oxidação dos ácidos graxos.

\subsection{Métodos para inibir a atuação das LOX na produção de leite de soja}

O processo convencional para a produção de leite de soja que tem sido utilizado por vários séculos no oriente envolve a maceração dos grãos em água, seguida por trituração, filtração e fervura. Embora este processo seja simples, a bebida resultante tem odor e flavor desagradáveis caracteristicos de tinta (ou óleo de linhaça) (Nelson et al., 1976).

Wilkens et al. (1967) estiveram entre os primeiros a identificar a atuação das lipoxigenases durante a maceração dos grãos de soja como responsáveis pelo desenvolvimento do "flavor" desagradável e a propor um processo de extração com água quente para inibí-las. Desde então, inúmeros trabalhos surgiram, propondo os mais diversos métodos para a inativação das lipoxigenases e obtenção de leite de soja com "flavor" agradável aos consumidores do ocidente. O tratamento térmico ainda é o mais utilizado, segundo Paula et al. (1995), podendo, quando inadequado, desnaturar e insolubilizar as frações protéicas limitando assim sua utilização.

Farkas \& Goldblith (1962) estudaram a cinética da inativação térmica da "lipoxidase", quando ainda não estava associada à origem do "flavor" desagradável dos produtos da soja. Seus resultados indicaram diminuição linear da atividade residual em relação ao tempo de aquecimento, característica de reação de primeira ordem, comum 
à inativação térmica de sistemas biológicos. Posteriormente, vários autores (Rice et al., 1981; Paula et al., 1995) também chegaram à mesma conclusão.

Baseando-se na separação e análise cromatográfica de compostos voláteis formados no processo de trituração de grãos de soja com água, Wilkens et al. (1967) concluíram que a formação destes compostos é inversamente proporcional à temperatura da água no início da trituração, cujo valor mínimo seria de $80{ }^{\circ} \mathrm{C}$ para impedir a formação substancial destes compostos.

Baker \& Mustakas (1973) estudaram os efeitos de aditivos químicos na inativação térmica de inibidores de tripsina, lipoxigenases e urease e verificaram que com a adição de ácidos ou bases, a inativação inicial de urease e das lipoxigenases foi significativamente acelerada. Sem aditivos, não houve inativação das lipoxigenases a $49^{\circ} \mathrm{C}$ e a completa inativação foi alcançada após 15 minutos a $82^{\circ} \mathrm{C}$.

Rice et al. (1981) estudaram os efeitos da inativação das lipoxigenases em grãos íntegros antes da extração do óleo bruto e obtenção da farinha. $\mathrm{O}$ tempo de aquecimento foi o principal fator na inativação térmica das lipoxigenases e uma relação de primeira ordem foi obtida entre a atividade das lipoxigenases e o tempo de aquecimento a $99^{\circ} \mathrm{C}$. Com os tratamentos, foram obtidos óleos com maior estabilidade oxidativa, melhores pontuações em avaliações organolépticas e farinhas também superiores em relação aos produtos obtidos sem tratamento.

Hildebrand \& Kito (1984) investigaram a inativação térmica de lipoxigenases em grãos com e sem a isoenzima L-1 (mutantes), com relação à geração de compostos voláteis nos produtos protéicos da soja. As evidências indicaram que o uso de 
variedades de soja deficientes em L1 podem reduzir o nível de compostos carbonílicos voláteis com um mínimo de aquecimento e perda de proteína.

Che Man et al. (1989) avaliaram um método de inativar as lipoxigenases da soja com retenção da solubilidade da proteína usando apenas ácido, sem o emprego de calor. Segundo estes autores, a inativação das lipoxigenases é irreversivel quando a soja é triturada em meios com pH menor que 3,0 independentemente do ácido utilizado.

Che Man et al. (1991), investigando o efeito da maceração de grãos de soja em soluções de $\mathrm{HCl}$ diluídas $(0,15$ e $0,30 \mathrm{M})$ sobre a atividade residual das lipoxigenases nas farinhas, verificaram que ela foi completamente eliminada pela maceração em solução $0,30 \mathrm{M}$ de $\mathrm{HCl}$ tanto a $23^{\circ} \mathrm{C}$ como a $4^{\circ} \mathrm{C}$, após 8 horas.

Badenhop \& Hackler (1970) estudaram os efeitos da maceração dos grãos de soja em soluções de hidróxido de sódio sobre o "flavor", a aceitação e o valor nutricional do leite resultante. A maceração de grãos de soja em solução de hidróxido de sódio aproximadamente $0,05 \mathrm{~N}$ por 2 horas a $50{ }^{\circ} \mathrm{C}$ é um pré-tratamento recomendável antes da operação de trituração em altas temperaturas para a produção de leite. Os autores (1970) relataram os efeitos da maceração de milho em soluções de hidróxido de sódio relacionada à liberação de niacina. Esta vitamina (ácido-3-piridino-carboxilico), também conhecida por ácido nicotínico ou nicotinamida, é um derivado ácido da piridina que consiste de um sistema de anéis aromáticos heterocíclicos análogo ao benzeno, com um grupo $\mathrm{CH}$ substituído por um átomo de nitrogênio. 
Bourne et al. (1976) também estudaram o efeito da adição de soluções alcalinas no processo de moagem com água em ebulição sobre o "flavor" do leite de soja, concluindo que a concentração de íon sódio é um mecanismo mais efetivo na melhoria do "flavor" do leite de soja que a mudança de $\mathrm{pH}$.

Nelson et al. (1976) propuseram um processo ("Illinois Process") de produção de leite de soja com "flavor" suave e livre do desagradável sabor de tinta. O processo inclui maceração em solução $0,5 \%$ de $\mathrm{NaHCO}_{3}$ e branqueamento, na mesma solução, a $82^{\circ} \mathrm{C}$ por 30 minutos para a inativação das lipoxigenases.

Hühn (1977) verificou que o íon cúprico inibe a formação de "sabores estranhos" durante a elaboração do leite de soja apresentando melhoria significativa no "flavor".

Borhan \& Snyder (1979) estudaram o efeito do tratamento combinado de calor e etanol sobre a soja para destruir a atividade da lipoxigenase, mantendo ainda uma considerável solubilidade e funcionalidade das proteínas. As faixas utilizáveis são de 15 a $45 \%$ de etanol, de $40{ }^{\circ} \mathrm{C}$ a $60^{\circ} \mathrm{C}$ e o tempo de exposição, de 2 a 6 horas. A combinação apropriada destas condições é suficiente para destruir as lipoxigenases e manter um nível de solubilidade de proteína de 50-60, mas apenas 50\% do inibidor de tripsina é destruído. Por exemplo, a lipoxigenase pode ser inativada pela maceração em solução de $15 \%$ de etanol a $50{ }^{\circ} \mathrm{C}$ por $6 \mathrm{~h}$. Estes pesquisadores também demonstraram que a inativação das lipoxigenases durante a maceração em soluções etanólicas é proporcional ao aumento do $\mathrm{pH}$. 
Ashraf \& Snyder (1981) também estudaram a maceração em soluções etanólicas mas, em pH alcalino, e obtiveram os melhores resultados de "flavor" com a maceração em soluções etanólicas a $15 \% \operatorname{com} 0,1 \mathrm{M}$ de $\mathrm{NaOH}$.

Pour-El et al. (1981) submeteram grãos de soja a aquecimento em microondas sob frequências diferentes e por vários períodos de tempo, e associaram as alterações de várias propriedades biológicas com a energia mínima absorvida (MEA) calculada a partir dos dados de temperatura e perda de água registradas nos tratamentos. Foi alcançada redução acima de $90 \%$ da atividade das lipoxigenases com MEA em torno de $150 \mathrm{cal} / \mathrm{g}$.

Wang \& Toledo (1987) estudaram a inativação das lipoxigenases de grãos de soja por aquecimento em forno de microondas e demonstraram que ela é rápida e mantém a extratabilidade das proteínas em níveis apropriados para a produção de leite. Em outro trabalho, Wang \& Toledo (1990) avaliaram o valor nutricional de leites de soja preparados a partir de grãos de soja tratados com microondas e concluíram que com este tipo de tratamento obtém-se produtos com alta digestibilidade das proteínas "in vitro", aumento dos aminoácidos que contém enxôfre e redução da atividade inibidora da tripsina. Todos estes estudos demonstraram que a radiação de microondas penetra rapidamente nos produtos, aquecendo-os em tempos muito inferiores àqueles dos processos convencionais. 


\subsection{Extração da fração lipídica}

A fração lipídica dos grãos de soja constitui em torno de $20 \%$ de seu peso total dependendo principalmente da variedade e das condições de plantio (Zangelmi et al., s.d.). Este óleo encontra-se em corpos lipídicos subcelulares chamados esferossomos cujos diâmetros variam entre 0,2 e $0,5 \mu$ (Wolf, 1978). Os lipídeos dos grãos de soja compreendem um grupo diverso de compostos, sendo os mais abundantes aqueles classificados como glicerolipídeos que consistem de ácidos graxos esterificados pelo glicerol (Wilson, 1987). Os ácidos graxos dos grãos de soja são os saturados (15\%), palmítico e esteárico; o monoinsaturado oléico $(24 \%)$, e os polinsaturados, linoléico (54\%) e linolênico (7\%) (Wilson, 1987).

Há três tipos principais de associações das quais os lipídeos participam nos tecidos de organismos vivos: i) forças de Van der Waals não polares; ii) pontes de hidrogênio e forças eletrostáticas; iii) ligações covalentes. Os lipídeos que estão em grande parte ligados por forças de Van der Waals ou hidrofóbicas, nas quais lipídeos neutros ou não polares estão ligados por forças relativamente fracas, podem ser extraídos com solventes relativamente não polares tais como clorofórmio, benzeno etc. Lipídeos polares associados a membranas, entretanto, requerem solventes com certa polaridade tais como etanol ou metanol, para romper as pontes de hidrogênio ou forças eletrostáticas entre os lipideos e as proteínas. Os lipídeos ligados covalentemente, ao contrário, não podem ser diretamente extraídos por quaisquer solventes porque primeiro deve ser clivada a ligação do complexo por hidrólise ácida ou alcalina (Nelson, 1991). 
A natureza química dos lipídeos a serem extraídos deve ser levada em consideração na escolha do procedimento e a temperatura de extração deve ser a ambiente a fim de retardar as reações de peroxidação e de hidrólise. Os procedimentos clássicos nos quais o tecido é extraído num extrator de Soxhlet com refluxo de solvente por muitas horas deve ser evitado (Kates, 1986). Quando o objetivo da extração da fração lipídica não é apenas a quantificação do teor total de lipídeos, mas também a sua análise, deve-se adotar um procedimento que não altere significativamente sua estrutura ou composição química (Lumley \& Colwell, 1991).

Um outro fator que deve ser considerado, principalmente com materiais vegetais, é a degradação enzimática dos lipídeos durante a extração. Em geral, o uso de misturas de solventes contendo álcool é suficiente para inativar muitas das fosfatidases e lipases; com enzimas muito estáveis, a imersão do tecido por 1 a 2 minutos em álcool quente ou água em ebulição irá inativá-las (Kates, 1986).

Das considerações acima, segue que o álcool é um componente essencial do solvente de extração, sendo necessário para o rompimento dos complexos lipídeo-proteína, a dissolução dos lipídeos e a inativação das enzimas. Porém, há o problema da co-extração (extração paralela) de contaminantes celulares tais como açúcares, aminoácidos, sais, etc. É, portanto, essencial que o extrato bruto seja tratado, para remover estes contaminantes solúveis em água. $\mathrm{O}$ procedimento mais comum utilizado é a lavagem do extrato com água, que pode levar à formação de emulsões (Kates, 1986). 
Muitos procedimentos de extração de lipídeos totais de materiais biológicos (inclusive alimentícios) baseados na mistura clorofórmio-metanol foram publicados e extensivamente utilizados (Lumley \& Colwell, 1991).

O procedimento proposto por Folch et al. $(1951 ; 1957)$ para a extração de lipídeos de cérebro e de tecidos animais é o mais amplamente conhecido. Muitas variações deste procedimento foram desenvolvidas e é necessário selecionar qual é o mais adequado aos objetivos propostos e ao material com que se trabalha.

Um dos procedimentos de extração mais versáteis e efetivos, que supera amplamente todas as dificuldades mencionadas acima, é o de Bligh \& Dyer (1959), uma versão simplificada do procedimento clássico de Folch et al. (1957).

Considerando principalmente os riscos potenciais, tanto à saúde como ao meio ambiente, dos métodos que se baseiam no uso da mistura clorofórmio-metanol, Hara \& Radin (1978) e Radin (1981) propuseram um método bastante simples baseado no uso de uma mistura de hexano-isopropanol, que possui baixa toxidez.

Para o caso específico da extração da fração lipídica de sementes, os métodos acima também podem ser utilizados. Khor \& Chan (1985) compararam três métodos que utilizam diferentes misturas de solventes para a extração da fração lipídica de grãos de soja. Estes foram extraidos com clorofórmio-metanol (2:1), de acordo com método de Folch et al. (1957), com cloreto de metila-metanol (2:1), de acordo com Chen et al (1981) e com hexano-isopropanol (3:2), de acordo com Hara \& Radin (1978). As diferentes frações lipídicas foram separadas e quantificadas por cromatografia em camada delgada. Concluiu-se que os resultados $(\% \mathrm{~m} / \mathrm{m})$ obtidos com a mistura cloreto de metila- 
metanol foram tão bons quanto os obtidos com clorofórmio-metanol mas, com a mistura hexano-isopropanol foram inferiores.

De La Roche \& Andrews (1973) avaliaram vários sistemas de solventes para a extração de lipídeos de sementes de trigo e demonstraram que a extração prévia com apenas isopropanol seguida pelo procedimento de Bligh \& Dyer (1959) foi o método mais eficiente em relação ao rendimento em lipídeos e à capacidade de inativar enzimas lipolíticas.

\subsection{Análise espectrofotométrica da fração lipídica}

A absorção espectrofotométrica seletiva entre os compostos orgânicos é relacionada a uma deficiência de elétrons na molécula. Compostos totalmente saturados não apresentam absorção seletiva nas regiões do visível e do ultravioleta e são úteis como solventes em determinações espectrais nesta região. A absorbância A é dada por $\mathrm{A}=\log \left(\mathrm{I}_{0} / \mathrm{I}\right)$ onde $\mathrm{I}$ é a intensidade de luz incidente e $\mathrm{I}_{0}$ é a intensidade da luz transmitida. O cálculo da intensidade de absorção envolve o uso das leis de Lambert e de Beer, relacionadas pela fórmula $\mathrm{E}=\mathrm{A} / \mathrm{c} \mathrm{x}$ b onde, $\mathrm{E}$ é o coeficiente de extinção molar, $\mathrm{c}$ é a concentração molar e b é a espessura da cubeta, em centímetros. Quando o peso molecular da substância não é conhecido, substitui-se a concentração molar pela concentração mássica dada em g / $100 \mathrm{ml} \mathrm{e,} \mathrm{o} \mathrm{coeficiente} \mathrm{de} \mathrm{extinção} \mathrm{molar} \mathrm{passa} \mathrm{a} \mathrm{ser}$ simplesmente coeficiente de extinção (Dyer, 1969). 
Compostos que contém uma dupla ligação absorvem fortemente no ultravioleta afastado (195 $\mathrm{nm}$ para o etileno, que é um cromóforo simples). As duplas ligações conjugadas (duplas e simples alternadas) tem absorção em comprimentos de onda maiores e, quanto mais extenso for o sistema conjugado, maiores serão os comprimentos de onda onde se observa a absorção (Ewing, 1972)

A oxidação de óleos que contém linoleato ou ácidos graxos mais insaturados (como é o caso do ácido linolênico, no óleo de soja) é acompanhada pela conjugação de duplas ligações que levam a um aumento progressivo da absorção de luz na região do ultravioleta (dienos em $234 \mathrm{~nm}$ e trienos em $268 \mathrm{~nm}$ ) (Gray, 1985). A magnitude da mudança não é diretamente relacionada ao grau de oxidação porque os efeitos sobre os vários ácidos graxos insaturados variam em qualidade e extensão. Entretanto, as variações no espectro ultravioleta de uma determinada substância podem ser usadas como medida relativa da oxidação (Gray, 1978).

St. Angelo et al. (1975) compararam os três métodos (índice de peróxido, aumento na absorção em $234 \mathrm{~nm}$ devido ao aumento de dienos conjugados e formação de malonaldeído - TBA) mais utilizados para a determinação da peroxidação em produtos de amendoim. Observaram que os resultados de absorbância dos hidroperóxidos com dienos conjugados podiam ser correlacionados com os índices de peróxido num período de armazenamento entre 4 e 12 semanas e concluiram que o método espectrofotométrico requer amostras menores, é mais rápido, mais preciso e mais simples do que o método iodométrico do índice de peróxido, além de não requerer reagentes adicionais nem depender de uma reação quimica ou desenvolvimento de cor. 


\subsection{Cultivar de soja "Davies"}

Segundo Barros et al. (1984) as atividades das lipoxigenases L-1 e L-3 do cultivar Davies possuem valores intermediários entre os cultivares de soja brasileiros (2940,19 U/mg proteína para L-1, entre valores que variam de 666,67 U/mg prot. (BR-5) a $4626,12 \mathrm{U} / \mathrm{mg}$ prot. (Santa Rosa) e $230,29 \mathrm{U} / \mathrm{mg}$ prot. para L3, entre valores que variam de $143,46 \mathrm{U} / \mathrm{mg}$ prot. (Jackson) a $309,38 \mathrm{U} / \mathrm{mg}$ prot. (IAC-3).

Turatti et al. (1979) analisaram quimicamente 25 amostras de diferentes cultivares de soja produzidas no Brasil quanto à composição de sólidos, proteína, matéria graxa, cinzas, fibras, atividade ureática e índice de dispersão de proteínas (PDI) e submeteram-nas à extração com água quente para produção de leite. Com base nos rendimentos em teor de sólidos, proteína e matéria graxa, selecionaram os 10 melhores e submeteram os respectivos leites à avaliação organoléptica. O cultivar Davies foi o que apresentou o melhor resultado no rendimento de extração e o terceiro melhor resultado na avaliação organoléptica. 


\section{MATERIAL E MÉTODOS}

\subsection{Material}

Grãos de soja da variedade Davies da safra $94 / 95$ foram obtidos do Centro Nacional de Pesquisa da Soja (CNPSo) da Empresa Brasileira de Pesquisa Agropecuária (EMBRAPA) - Londrina - PR.

Para as macerações dos grãos íntegros e preparo das diversas soluções de maceração utilizou-se água obtida no comércio local.

\subsection{Métodos}

\subsubsection{Análises de caracterização dos grãos}

Os grãos de soja obtidos para este estudo foram caracterizados pelas seguintes análises e métodos:

Teor de óleo - A.O.C.S., 1991 - Método Ac 3-44;

Teor de proteína - A.O.A.C., 1970 - Método micro-Kjeldahl; 
Teor de umidade - Instituto Adolfo Lutz, 1985 - Método 6.1.1.2;

Teor de cinzas - Instituto Adolfo Lutz, 1985 - Método 4.8;

Teor de carboidratos - calculado pela diferença percentual (100 - teores dos outros componentes).

Todos os teores foram determinados em porcentagem mássica $(\% \mathrm{~m} / \mathrm{m})$ em base seca, exceto a umidade.

Para a verificação da qualidade dos grãos também foram realizadas as seguintes análises da fração lipídica:

Extração em extrator tipo Butt (A.O.C.S., 1991 - método Ac 3-44; modificado para utilização de $20 \mathrm{~g}$ de amostra e extração por 16 horas) Índice de acidez - Instituto Adolfo Lutz, 1985 - Método 17.1; Índice de peróxido - A.O.C.S., 1991 - método Cd 8-53; Coeficiente de extinção - IUPAC, 1979 - método II.D.23.

\subsubsection{Tratamentos}

Os grãos de soja foram submetidos a quatro tipos de tratamentos independentes.

I) Maceração de grãos íntegros em diferentes temperaturas

Grãos de soja íntegros e em boas condições, selecionados manualmente, foram submetidos a macerações em várias temperaturas. Pesaram-se $50 \mathrm{~g}$ 
de grãos que foram imersos em água $(150 \mathrm{ml})$ a temperaturas ambiente $\left(22^{\circ} \mathrm{C}\right), 50^{\circ}, 60^{\circ}$, $70^{\circ}, 80^{\circ}$ e $98^{\circ} \mathrm{C}$ até absorção de água equivalente a 8 horas de maceração à temperatura ambiente (aproximadamente 1,1 vezes a massa inicial para o cultivar Davies) e depois de liofilizados tiveram a fração lipídica extraída e analisada. As macerações às temperaturas acima da ambiente foram realizadas em banho-maria.

II) Maceração de grãos íntegros aquecidos em forno de microondas

Grãos de soja integros e em boas condições, selecionados manualmente, foram submetidos a aquecimento em forno de microondas por diversos períodos de tempo. Pesaram-se $150 \mathrm{~g}$ de grãos que foram distribuídos em três placas de Petri (50g/placa) de 8,5-9,0 cm de diâmetro cada uma, levadas e dispostas ao centro do prato rotativo do forno de microondas marca Sanyo, modelo EM - 804TGR. Os grãos foram aquecidos na potência máxima do microondas $(800 \mathrm{~W})$, à $2450 \mathrm{MHz}$ de freqüência, por tempos de $30,60,90,120$ e 150 segundos. Ao final dos tratamentos, a porta do forno de microondas foi aberta e imediatamente feita a medida da temperatura da amostra com o auxilio de termopar de cobre-constantan da marca Tecnal, modelo Checktemp 1. Ao final da tomada de temperatura, esperou-se os grãos esfriarem até temperatura ambiente e realizou-se novamente a pesagem para verificação da perda de água. A seguir, os grãos foram macerados em água por 8 horas à temperatura ambiente como descrito no ítem anterior e, depois de liofilizados tiveram a fração lipídica extraída e analisada. 
III) Maceração de grãos íntegros em diferentes soluções à temperatura ambiente

Grãos de soja integros e em boas condições, selecionados manualmente, foram submetidos a macerações em diversas soluções. Pesaram-se $50 \mathrm{~g}$ de grãos que foram imersos em água (referência) e nas soluções (também preparadas com a mesma água) de $\mathrm{HCl} 0,30 \mathrm{M}$, de $\mathrm{NaHCO}_{3} 0,5 \%$, de etanol $15 \%(\mathrm{v} / \mathrm{v})$, de $\mathrm{NaOH} 0,05 \mathrm{~N}$ e de $\mathrm{Cu}^{2+} 12 \mathrm{ppm}\left(\mathrm{CuSO}_{4} \cdot 5 \mathrm{H}_{2} \mathrm{O}\right)$. Todas as macerações foram realizadas por $8 \mathrm{~h}$ à temperatura ambiente (bulbo seco $=26^{\circ} \mathrm{C}$ e bulbo úmido $=22^{\circ} \mathrm{C}$ ) e na proporção de $3: 1$ entre volume de solução (ou água) e massa de grãos. Após as macerações os grãos foram drenados, lavados com água, levados ao congelador $\left(-18^{\circ} \mathrm{C}\right)$ e depois liofilizados até recuperação aproximada do peso inicial.

Após serem liofilizados, os grãos foram submetidos à extração e análise da fração lipídica.

IV) Maceração de grãos triturados

O objetivo desta etapa foi promover a oxidação da fração lipídica dos grãos de soja catalisada pelas lipoxigenases. Aproximadamente $10 \mathrm{~g}$ de grãos de soja selecionados manualmente foram triturados para descompartimentalização das enzimas lipoxigenases (proteínas) e de seus substratos, os ácidos graxos (lipídeos), em moinho tipo ciclone (marca Marconi) e peneirados em peneira $\mathrm{n}^{\circ} 30$ (série ASTM que corresponde a $595 \mu \mathrm{m}$ de abertura ou 28 mesh na denominação Tyler equivalente) para a 
retirada das partículas maiores e garantir a homogeneidade da amostra. Após homogeneização manual do pó (farinha integral de soja) pesou-se $1 \pm 0,0003 \mathrm{~g}$ em tubos de ensaio $(10 \mathrm{~cm} \times 3 \mathrm{~cm})$. Com a amostra no tubo de ensaio promoveu-se efetivamente a oxidação catalisada pelas lipoxigenases através da adição de $1,2 \mathrm{ml}$ de água ou das mesmas soluções utilizadas para maceração dos grãos apresentadas no item anterior. Promoveu-se a mistura com o auxilio de bastão de vidro, manualmente. Após um tempo t (em minutos) de reação, procedeu-se diretamente à extração da fração lipídica conforme ítem 4.2.3.

\subsubsection{Extração da fração lipídica}

A extração da fração lipídica das amostras submetidas aos tratamentos descritos nos ítens anteriores foi feita pelo método de Hara \& Radin (1978) modificado. Uma extração inicial foi realizada apenas com isopropanol, como no método utilizado por De La Roche \& Andrews (1973), seguido pela aplicação do método de Hara \& Radin (1978), substituindo-se a mistura hexano-isopropanol pela de isooctano-isopropanol (ISO-ISP).

Os grãos integros macerados em diferentes temperaturas, nas várias soluções e em água após aquecimento em forno de microondas, depois de liofilizados, foram triturados, peneirados (peneira nº 30 série ASTM) e submetidos à extração. Após homogeização do pó, pesou-se $1 \pm 0,0003 \mathrm{~g} \mathrm{em}$ tubos de ensaio $(10 \mathrm{~cm} \times 3 \mathrm{~cm})$. Os grãos triturados e adicionados de água ou de uma das soluções de maceração testadas, tiveram 
a reação interrompida com o início da extração após um período de tempo $t$ (minutos) após a mistura.

A extração foi realizada pela adição de $8 \mathrm{ml}$ de isopropanol com mistura em homogeneizador tipo Potter (marca Novatécnica) por 1 minuto. Seguiu-se à imediata adição de $12 \mathrm{ml}$ de isooctano com mistura no mesmo homogeneizador por também 1 minuto. Filtrou-se a vácuo, ressuspendeu-se a farinha decantada no fundo do tubo em $5 \mathrm{ml}$ de mistura isooctano-isopropanol (ISO-ISP) 3:2 e filtrou-se novamente. $\mathrm{O}$ filtrado coletado em "kitassato" foi transferido para tubo de ensaio onde recebeu outros 5 ml da mistura ISO-ISP 3:2 utilizada na lavagem do "kitassato". Adicionaram-se, então, $12 \mathrm{ml}$ de solução de sulfato de sódio (preparada na concentração de $1 \mathrm{~g}$ de $\mathrm{Na}_{2} \mathrm{SO}_{4}$ anidro/15 ml de solução), misturou-se por 1 minuto no misturador Potter e transferiu-se todo o conteúdo para tubo de ensaio. Após a separação das fases, retirou-se uma amostra de $5 \mathrm{ml} \mathrm{da}$ fase superior (miscela rica em isooctano) com pipeta volumétrica, que foi transferida para placa de Petri previamente tarada para determinação do conteúdo de óleo e, outra, de $2 \mathrm{ml}$, que foi transferida para balão volumétrico de $25 \mathrm{ml}$ cujo volume se completou com mistura ISO-ISP 3:2 para análise espectrofotométrica.

\subsubsection{Análise espectrofotométrica da fração lipídica}

A solução do balão volumétrico de $25 \mathrm{ml}$ contendo a fração lipídica extraida foi analisada quanto à absorção de luz ultravioleta no comprimento de onda de $232 \mathrm{~nm}$, utilizando-se como referência a mesma mistura isooctano-isopropanol 3:2 
utilizada na extração. $\mathrm{O}$ volume de $2 \mathrm{ml}$ de miscela tomado para diluição até $25 \mathrm{ml}$ permitiu a obtenção de leituras de absorbâncias entre 0,2 e 0,8 garantindo assim maior precisão dos resultados conforme Ewing (1972).

Determinou-se o coeficiente de extinção pela fórmula (IUPAC, 1979):

$$
\mathrm{E}=\frac{\mathrm{A}_{232 \mathrm{~nm}}}{\mathrm{cxb}}
$$

onde: $\mathrm{A}_{232 \mathrm{~nm}}$ é a absorbância no comprimento de onda de $232 \mathrm{~nm}$; c é a concentração mássica de óleo em g/100 ml; b é a largura da cubeta de quartzo $(1 \mathrm{~cm})$.

\subsubsection{Análise estatística}

Todas as análises estatísticas (Steel \& Torrie, 1980) dos resultados experimentais foram realizadas considerando-se o delineamento inteiramente casualizado com aplicação do teste $F$ para verificação da existência de diferença significativa, sempre ao nivel 0,05 de significância $(\mathrm{p}<0,05)$, entre as médias. Para a comparação da eficiência entre os métodos de extração, aplicou-se o teste de Tukey. Para grãos macerados em diferentes temperaturas e àqueles aquecidos em forno de microondas aplicou-se a técnica da análise de regressão com escolha de um modelo de regressão conveniente que se ajustasse aos resultados experimentais do coeficiente de extinção. Para comparação com o coeficiente de extinção da fração lipídica de grãos não macerados aplicou-se o teste de Dunnett. Também se ajustaram as curvas aos resultados do coeficiente de extinção da 
fração lipídica de grãos triturados e adicionados de água (ou soluções testadas) em função do tempo. A qualidade do ajuste foi verificada pelo coeficiente de determinação, representado por $\mathrm{R}^{2}$, valores próximos a 1 indicam que a curva se ajusta totalmente aos dados.

Para grãos macerados em diferentes soluções aplicou-se o teste de Tukey para a verificação das diferenças entre as médias dos coeficientes de extinção.

Todos os cálculos estatísticos foram realizados com o programa STATISTICA. 


\section{RESULTADOS E DISCUSSÃO}

\subsection{Características do cultivar estudado}

\subsubsection{Composição química dos grãos}

A composição química dos grãos de soja do cultivar Davies foi determinada pelos métodos apresentados no ítem 4.2.1. Os resultados obtidos encontram-se na Tabela 1.

Tabela 1 - Composição química dos grãos de soja do cultivar Davies

\begin{tabular}{lc} 
Análise & $\% \mathrm{~m} / \mathrm{m}$ \\
\hline Umidade & 9,04 \\
Proteína $^{1}$ & 37,46 \\
Óleo $^{l}$ & 23,87 \\
Carboidrato $^{1,2}$ & 33,26 \\
Cinza $^{l}$ & 5,41 \\
& \\
\hline${ }^{1}$ Teores expressos em base seca. $^{2}$ Calculado por diferença percentual. & \\
\end{tabular}


Estes resultados estão bastante próximos aos encontrados, para o mesmo cultivar, por Mandarino et al. (1992) e também por Turatti et al. (1979).

\subsubsection{Análises da fração lipídica extraída}

Para se ter uma idéia inicial do estado do óleo contido nos grãos das amostras obtidas, procedeu-se à extração do mesmo em extrator tipo Butt e analisaramse os índices de acidez, de peróxido e o coeficiente de extinção (dienos conjugados) em $232 \mathrm{~nm}$ conforme métodos também apresentados no ítem 4.2.1. Os resultados encontramse na Tabela 2.

Tabela 2 - Coeficiente de extinção e índices de acidez (I.A.) e de peróxido (I.P.) do óleo extraído (óleo bruto) do cultivar Davies.
I.A. $(\% \mathrm{~m} / \mathrm{m})^{1}$
0,76
I.P. $(\mathrm{mEq} / \mathrm{kg})$
1,84
Coef. de extinção ${ }^{2}$
3,05

\footnotetext{
TExpresso em ácido oléico.

${ }^{2}$ Calculado pela fórmula: $\mathrm{A}_{232 \mathrm{~mm}} / \mathrm{C}(\mathrm{g} / 100 \mathrm{ml}) \times 1 \mathrm{~cm}$ com a média dos resultados de $\mathrm{A}_{232 \mathrm{~mm}}$ entre $0,2 \mathrm{e}$ 0,8 (ítem 5.3 - Figura 3).
}

Os limites máximos estabelecidos para óleo virgem comestível (extraido exclusivamente por processo mecânico), pela Resolução № 22/77 da Comissão Nacional de Normas e Padrões para Alimentos (Brasil, 1981), são de 2,0\% e $20 \mathrm{mEq} / \mathrm{Kg}$ para os índices de acidez e de peróxido, respectivamente. Portanto, considerando que a extração 
do óleo para a obtenção dos dados da Tabela 2 foi por solvente em extrator tipo Butt e secagem em estufa a $105^{\circ} \mathrm{C}$, pode-se dizer que a fração lipídica dos grãos estudados estava em boas condições.

\subsubsection{Absorção de água nas macerações}

$\mathrm{Na}$ maceração de grãos de soja ocorre a absorção de água com o conseqüente aumento de volume (intumescimento) dos mesmos. Para se verificar as alterações fisicas que ocorrem no processo de maceração, $100 \mathrm{~g}$ de grãos foram macerados por aproximadamente 15 horas (pernoite) à temperatura ambiente. A Tabela 3 apresenta os resultados obtidos para as características físicas dos grãos no início (antes) e após pernoite sob maceração. As massas e os volumes real e aparente foram medidos diretamente, sendo que o volume real foi determinado verificando-se o volume de água deslocado numa proveta.

Grãos de soja maduros e íntegros, quando embebidos em água absorvem-na até atingirem em torno de 2,2 vezes o seu peso seco original (Zangelmi et al., s.d.). Para o cultivar Davies houve absorção de água até os grãos atingirem 2,3 vezes o seu peso original conforme indicado na Tabela 3. 
Tabela 3 - Alteração das características físicas dos grãos na maceração (pernoite à temperatura ambiente)

Característica fisica

Massa (g)

Volume:

aparente $(\mathrm{ml})$

real $(\mathrm{ml})$

Densidade: aparente $(\mathrm{g} / \mathrm{ml})$

real $(\mathrm{g} / \mathrm{ml})$
Antes

100

138

80

0,725

1,25
Após (pernoite)

O processo de maceração depende, na realidade, do tempo e da temperatura, além da variedade do grão de soja. A Figura 2 apresenta as curvas aproximadas de absorção de água pelo cultivar Davies para várias temperaturas. Desta Figura conclui-se que a velocidade de absorção de água é proporcional à temperatura de maceração. Os grãos de soja absorvem água rapidamente nas duas primeiras horas seguido de uma absorção mais lenta (Wang et al., 1979).

As curvas da Figura 2, que mostram valores experimentais de água absorvida pelos grãos de soja, podem ser representadas com boa aproximação, por funções polinomiais de $2^{\underline{a}}$ ordem do tipo: $M_{\text {grãos }}=-\mathrm{At}^{2}+\mathrm{Bt}+\mathrm{C}$ onde $\mathrm{M}_{\mathrm{grãas}}$ é a massa de grãos de soja, t é o tempo de maceração, $\mathrm{C}=52,086$ e, A e B são, por sua vez, funções da temperatura $\left(\mathrm{T}\right.$ em $\left.{ }^{\circ} \mathrm{C}\right)$ expressas por $\mathrm{A}=5 \times 10^{-6} \mathrm{~T}^{3,6974}\left(\mathrm{R}^{2}=0,9704\right) \mathrm{e}$ $B=0,0302 T^{1,8705}\left(R^{2}=0,9725\right)$. Todas as curvas ajustadas apresentaram $R^{2}>0,99$ com 
exceção para a temperatura de $98^{\circ} \mathrm{C}$, na qual a absorção de água é muito rápida, que ficou em 0,9722 .

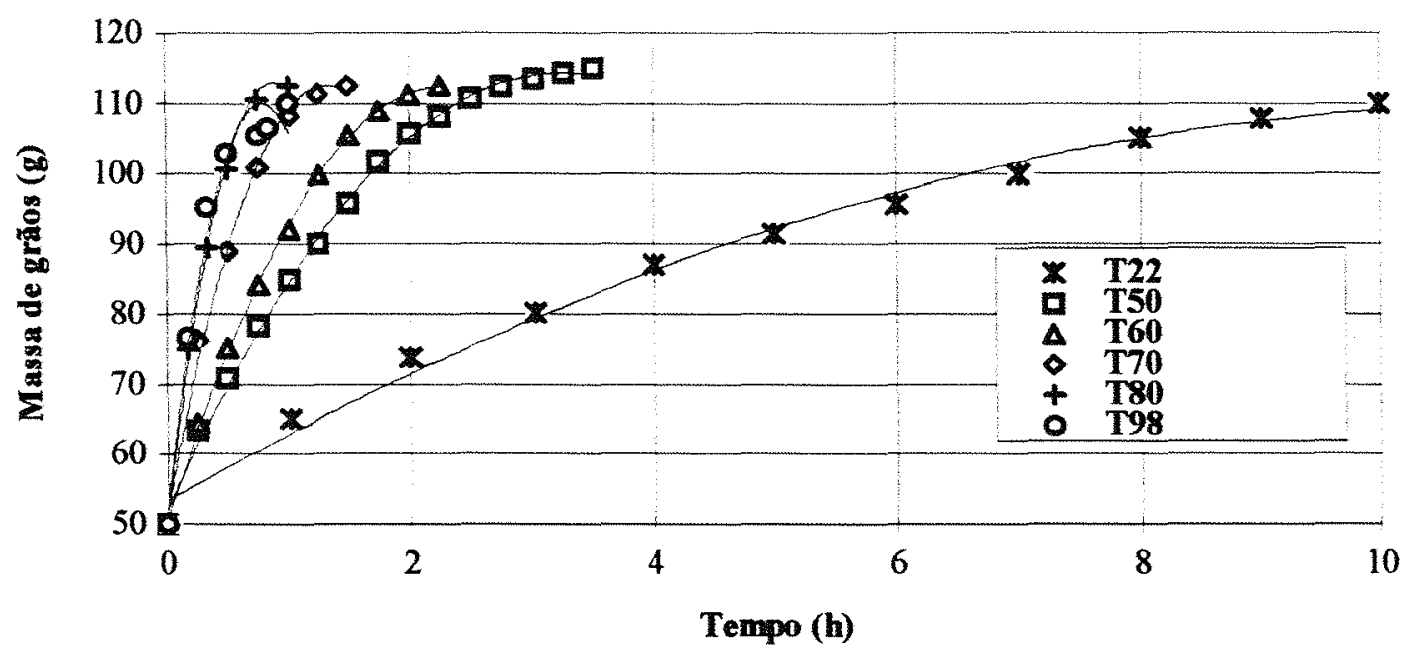

Figura 2 - Curvas de absorção de água pelo cultivar Davies em várias temperaturas

(Os pontos são dados experimentais enquanto a linha contínua representa a curva ajustada a um polinômio de $2^{\mathrm{a}}$ ordem).

A absorção de água pelas sementes é a etapa inicial e essencial do processo de germinação (Bewley \& Black, 1994). Vários fatores governam a absorção de água pelo grão mas particularmente importante é a diferença de umidade entre o grão e o meio externo que o envolve. A força motriz da transferência de água do meio externo para o interior do grão é, portanto, a diferença de potencial da água entre o meio externo e o interior do grão. A difusão líquida de água ocorre do meio de maior potencial (no caso, o meio externo) para o de menor potencial (interior do grão). A água pura possui o mais alto potencial que, por convenção, recebe o valor zero. O potencial da água de um 
grão seco e maduro é muito menor que qualquer solução aquosa que o envolva de modo que quando os grãos são imersos em tais soluções, a absorção ocorre, numa primeira fase, independentemente dele estar dormente ou não, viável ou não como semente. A absorção inicial de água compreende três fases: (1) uma nítida fronteira que separa as porções úmida e seca do grão, (2) contínuo intumescimento das novas regiões que a água alcança e, (3) um aumento no conteúdo de água das áreas já úmidas.

\subsection{Extração da fração lipídica}

De acordo com os objetivos expostos, de analisar a fração lipídica de grãos macerados em diversas condições, foi necessário utilizar um método de extração rápido, eficiente e que provocasse alteração mínima na fração lipídica. Os métodos padrões para a extração da fração lipídica de sementes oleaginosas baseiam-se no uso de extratores do tipo Soxhlet ou similares, nos quais hexano ou éter de petróleo refluxam através da amostra por várias horas. Optou-se por um dos métodos de extração da fração lipídica de tecidos de organismos vivos que utilizam misturas de solventes polares e apolares e são muito rápidos e aplicados à temperatura ambiente.

Para a extração das frações lipidicas das amostras submetidas aos tratamentos nesta pesquisa, utilizou-se o método de Hara \& Radin (1978) modificado. As modificações introduzidas foram as seguintes:

- no caso de grãos triturados e adicionados de água (ou solução) para verificação da curva de oxidação, a amostra a ser extraída constituiu-se de $2,2 \mathrm{~g}$ (1 g 
amostra $+1,2$ ml de água) e não $1 \mathrm{~g}$ como se recomenda. Para grãos íntegros macerados e liofilizados, utilizou-se de $1 \mathrm{~g}$ da amostra preparada para extração;

- substituição da mistura hexano-isopropanol (3:2) por isooctanoisopropanol (3:2);

- mistura prévia por 1 minuto apenas com isopropanol antes da adição de isooctano para constituir a mistura 3:2; portanto, o tempo total de extração foi de 2 minutos ( 1 minuto de mistura com isopropanol seguido por 1 minuto de mistura após adição de isooctano) e não 1 min como no método original onde se adiciona a mistura 3:2 e se agita por 1 minuto;

Estas modificações se justificam pelos fatos apresentados a seguir.

$\mathrm{Na}$ extração dos grãos triturados e adicionados de água (ou das soluções), a adição prévia de isopropanol permitiu uma imediata solubilização da amostra uma vez que este solvente e a água são miscíveis em praticamente todas as proporções. Estando a água dissolvida no isopropanol, para efeitos práticos, tem-se apenas $1 \mathrm{~g}$ do tecido de onde interessa extrair a fração lipídica, ou seja, $1 \mathrm{~g}$ de soja na amostra. A adição de isooctano constituiu a mistura 3:2 de extração do método original, sendo que os 1,2 ml de água (ou solução) adicionados devem ter pouca influencia na extração e serviram para se verificar os seus efeitos na atuação das lipoxigenases. Os resultados de extração mostrados na Tabela 4 confirmam estas hipóteses. A adição de água ao grão triturado pode interferir na leitura das absorbâncias dos extratos conforme se apresenta no item 5.4.4. 
A escolha do solvente para a extração dos lipideos deve ser feita com base em vários fatores: volatilidade (para o caso de ser necessária sua remoção após a extração), ausência de impurezas, como agentes tóxicos ou que reajam com os lipídeos, capacidade de formar um sistema de duas fases com a água (para remoção dos nãolipídeos), capacidade de extração de componentes indesejáveis (lipoproteínas, pequenas moléculas), preço, poder de extração dos diferentes tipos de lipideos e, transparência na região de luz ultravioleta para análises subsequentes, espectrofotométricas ou em colunas cromatográficas (Hara \& Radin, 1978). Após a consideração destes vários fatores, Hara \& Radin (1978) optaram pela mistura Hexano-Isopropanol com a qual desenvolveram método para a extração da fração lipídica de tecidos de organismos vivos (particularmente de cérebros de camundongos e ratos). Dentre as propriedades fisicas que influem na extração, a maior diferença entre o isooctano e o hexano é o ponto de ebulição que é de $99,2{ }^{\circ} \mathrm{C}$ para o isooctano, enquanto a do hexano é de $69,0{ }^{\circ} \mathrm{C}$. Obviamente, a substituição do hexano por isooctano não é interessante se se deseja a remoção do solvente após a extração, que não foi o caso. Após a extração, a miscela foi submetida diretamente à análise espectrofotométrica depois de ser apenas diluída no próprio solvente de extração. $\mathrm{O}$ uso do isooctano foi decidido aqui porque este é o solvente utilizado no método para verificação de deterioração de óleos da I.U.P.A.C. (1979) por espectrofotometria. O fato do isooctano ser pouco volátil constitui aqui uma vantagem adicional, pois há menores perdas deste solvente na filtração a vácuo durante o processo de extração. 
De La Roche \& Andrews (1973) testaram vários métodos que utilizam diferentes solventes para a extração da fração lipídica de sementes de trigo. Verificaram que com a extração prévia com isopropanol seguida da aplicação do método de Bligh \& Dyer (1959), extraiu-se muito mais lipídeos neutros que com o método de Bligh \& Dyer isoladamente. Por este fato, introduziu-se a adição prévia de isopropanol no procedimento de extração de Hara \& Radin (1978) utilizado neste trabalho. Isto facilitou muito a solubilização da amostra na mistura solvente pois como já se disse, a água e o isopropanol são miscíveis.

Para se verificar os efeitos das modificações introduzidas, compararamse os resultados quanto ao teor de óleo extraído pelo método utilizado neste trabalho (Hara \& Radin, 1978 modificado) com o método convencional em extrator tipo Butt.

Na Tabela 4 apresentam-se os resultados dos teores de óleo obtidos. No método que utiliza o extrator tipo Butt manteve-se a amostra sob refluxo de hexano comercial por aproximadamente dezesseis horas.

$\mathrm{Na}$ aplicação de todos estes métodos de extração, as amostras foram trituradas aumentando muito a área superfícial exposta à atuação do solvente e diminuindo a distância que o mesmo deve percorrer para atingir os esferossomos e, portanto, a fração lipídica dos grãos. 
Tabela 4 - Comparação da eficiência dos métodos de extração

Método
Teor de óleo extraído $(\% \mathrm{~m} / \mathrm{m})^{*}$

1.Refluxo de hexano em extrator Butt ${ }^{1}$ :

Fração fina

Fração grossa

Total $22,29^{\mathrm{a}}$

14,91

21,70

2. Hara \& Radin ( $1 \mathrm{~g}$ de fração fina seca) ${ }^{2}$

Hexano-Isopropanol 3:2

$21,31^{\mathrm{b}}$

Isooctano-Isopropanol 3:2

$21,52^{\mathrm{b}}$

3. Hara \& Radin (1g de fração fina

adicionada de $1,2 \mathrm{ml}$ de água) ${ }^{2}$

Hexano-Isopropanol 3:2

$20,98^{\mathrm{b}}$

Isooctano-Isopropanol 3:2

${ }^{1}$ A.O.C.S.(1991)

${ }^{2}$ Hara \& Radin (1978)

"Os valores com as mesmas letras sobrescritas não diferem entre si ( $\mathrm{p}<0,05 \%)$ pelo teste de Tukey.

Através do peneiramento da farinha integral da soja em peneira $n^{0} 30$ (série ASTM que corresponde a $595 \mu \mathrm{m}$ de abertura ou 28 mesh na denominação Tyler equivalente) e extração do óleo da fração grossa (retida na peneira) constatou-se que a mesma possui teor de óleo bem menor que a fração fina, que passou pela peneira (Tabela 4). Na média, a fração grossa representou aproximadamente $8 \%$ do grão donde se conclui que o teor de óleo contido nesta fração em relação ao grão íntegro está em torno 
de $1,2 \%(14,91 \times 0,08)$. Com base nestes resultados decidiu-se pelo descarte da fração grossa nas extrações das frações lipidicas o que garantiu maior homogeneidade das amostras, uma vez que se tomou apenas $1 \mathrm{~g}$ das mesmas para cada extração.

A aplicação do teste de Tukey mostrou que não há diferença significativa $(p<0,05 \%)$ entre as médias do teor de óleo extraido pelo método Butt $(22,29 \%)$ e as do extraído com isopropanol-isooctano da fração fina de grãos adicionados de água $(22,36 \%)$. São, porém, diferentes dos resultados obtidos com os demais métodos, os quais não diferem significativamente entre si. A maior diferença percentual entre os valores de teor de óleo extraído foi em torno de $6 \%$. Se as extrações não foram seletivas e métodos idênticos foram aplicados aos grãos submetidos aos mesmos tratamentos, pode-se considerar que extrações não quantitativas não constituíram impedimento à realização deste trabalho.

\subsection{Características espectrofotométricas da fração lipídica}

A Figura 3 apresenta o gráfico de absorbância (A) em função da concentração (c) de dois óleos extraídos de grãos de soja em extrator tipo Butt. O óleo que se chama de "oxidado" corresponde àquele extraido de grãos que foram triturados e misturados com água destilada na proporção (em peso) de 1 parte de grãos para 1,2 partes de água por 1 hora à temperatura ambiente, levados ao congelador $\left(-18^{\circ} \mathrm{C}\right) \mathrm{e}$ depois liofilizados. Assim, as lipoxigenases devem ter promovido a oxidação da fração lipídica, o que foi constatado através das análises de absorção de luz ultravioleta em 
$232 \mathrm{~nm}$ e determinação do índice de peróxido. O óleo bruto corresponde ao que foi extraído de grãos apenas triturados, sem tratamento nenhum.

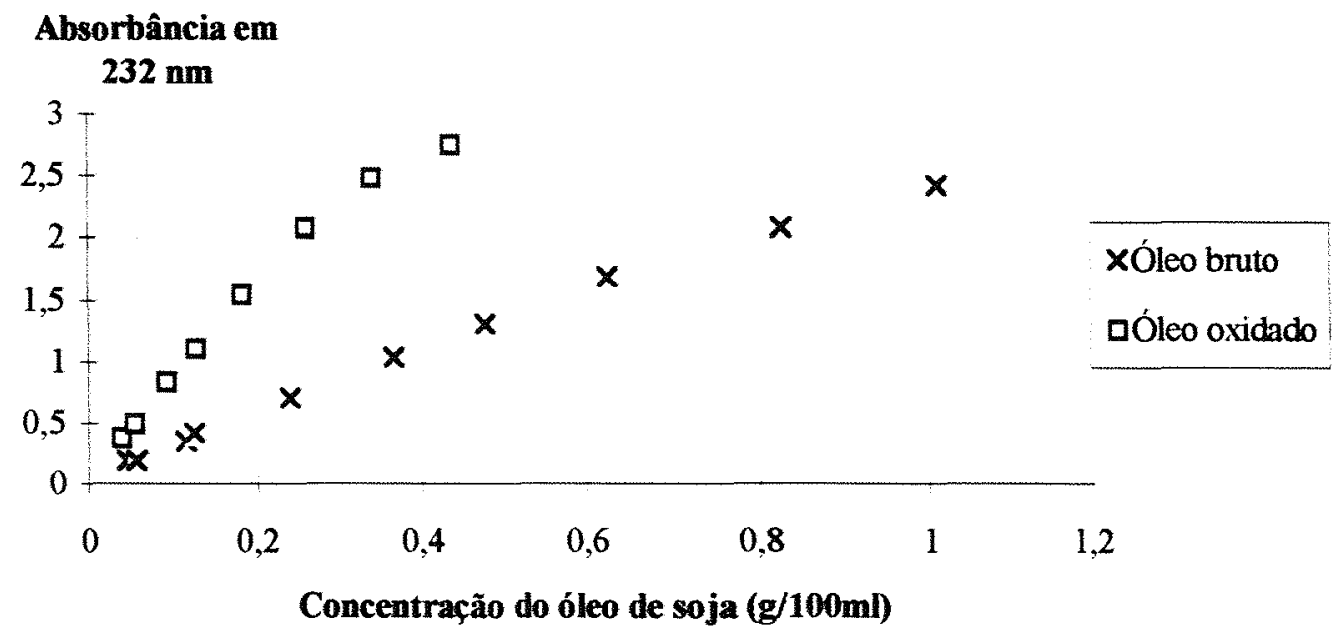

Figura 3 - Leituras de absorbância em $232 \mathrm{~nm}$ em função da concentração de óleo (Os óleos foram diluídos em isooctano puro em balð̌es de $25 \mathrm{ml}$; solvente de referência).

Pode-se observar na Figura 3 que a Lei de Beer $(A=K$ x c, ou seja, a absorbância é diretamente proporcional ao número de moléculas absorventes) é obedecida até uma determinada concentração de óleo a partir da qual há um desvio negativo e que quanto mais oxidado é o óleo, mais baixa é esta concentração limite. $O$ desvio pode ocorrer devido à interação das moléculas do soluto (neste caso, o óleo) entre si ou com o solvente (Ewing, 1972).

Segundo o método II.D.23 da I.U.P.A.C. (1979) para determinação de pureza e deterioração por espectrofotometria no ultravioleta de óleos vegetais e gorduras, deve-se pesar uma massa de amostra tal que a absorbância da solução esteja entre 0,2 e 0,8 . Isto é necessário para que se garanta uma maior precisão da análise; o 
erro mínimo ocorre quando a transmitância é de aproximadamente $36,8 \%$ (absorbância $=0,430$ ), sendo que no intervalo de transmitância entre 15 e $65 \%$ (absorbância 0,8 a 0,2 ) a precisão da análise não é significantemente alterada (Ewing, 1972).

Da Figura 3 pode-se observar que para absorbâncias entre 0,2 e 0,8 correspondem concentrações de óleo bruto entre 0,070 e $0,300 \mathrm{~g} / 100 \mathrm{ml}(0,02$ a $0,08 \mathrm{~g}$ de óleo em $25 \mathrm{ml}$, aproximadamente) e de óleo oxidado entre 0,020 e $0,100 \mathrm{~g} / 100 \mathrm{ml}$ $(0,005$ a $0,025 \mathrm{~g}$ de óleo em $25 \mathrm{ml}$, aproximadamente). Dessa forma, quanto mais oxidado o óleo, menores quantidades devem ser diluídas em $25 \mathrm{ml}$ para se obter maior precisão nas medidas de absorbâncias.

Estas limitações existem mesmo para sistemas que não mostrem desvios quanto à lei de Beer. Em concentrações elevadas, passa tão pouca energia radiante que a sensibilidade do fotômetro torna-se inadequada e em baixas concentrações, o erro inerente à leitura do galvanômetro ou a outro dispositivo indicativo torna-se grande em comparação com a quantidade que está sendo medida (Ewing, 1972).

Os coeficientes de extinção (E) dos óleos bruto e oxidado também podem ser determinados a partir da Figura 3. Para calculá-los, basta tomar qualquer valor de concentração de óleo (na abscissa) onde a lei de Beer é obedecida e a correspondente absorbância na ordenada e aplicar a fórmula $E=A / \mathrm{c}(\mathrm{g} / 100 \mathrm{ml}) \times 1 \mathrm{~cm}$. Através da regressão linear obteve-se a reta que melhor representa os pontos até onde a lei de Beer é obedecida e a partir desta encontrou-se os valores médios dos coeficientes de extinção de 3,05 (apresentado na Tabela 2) para o óleo bruto e de 8,92 para o óleo oxidado. 
Os indices de peróxido dos óleos bruto e oxidado medidos foram de 1,84 (Tabela 2) e 5,5, respectivamente. Houve portanto, uma relação bastante grande entre aumento do índice de peróxido $(5,50 / 1,84=2,98)$ e do coeficiente de extinção $(8,92 / 3,05=2,92)$ confirmando que através do coeficiente de extinção é possivel a determinação do grau relativo de oxidação da fração lipídica.

No método de extração utilizado neste trabalho, obteve-se miscelas (solvente mais fração lipídica extraída) com teores de óleo entre 1,2 e $1,5 \mathrm{~g} / 100 \mathrm{ml}$, das quais se tomaram alíquotas de $2 \mathrm{ml}$ que diluídas para $25 \mathrm{ml}$ constituíram as soluções que tiveram suas absorbâncias determinadas. Estas soluções tiveram então concentrações de óleo na faixa entre 0,10 e $0,12 \mathrm{~g} / 100 \mathrm{ml}$, garantindo assim, a precisão das medidas das absorbâncias.

Outra questão cuja discussão se faz necessária, é o efeito do tipo de solvente utilizado para a diluição da miscela de óleo extraída. Para os resultados da Figura 3, utilizou-se isooctano puro nas diluições, mas as alíquotas de miscela extraídas neste trabalho foram diluídas com uma mistura de isooctano-isopropanol (ISO-ISP) 3:2. Para verificar o efeito da mudança do tipo de solvente sobre o coeficiente de extinção, foram feitas determinações para um mesmo óleo, utilizando-se isooctano puro e a mistura ISO-ISP 3:2. Os resultados obtidos encontram-se na Tabela 5.

Como se pode observar pelos valores das médias obtidas (Tabela 5), quando se utiliza a mistura ISO-ISP 3:2 para diluição das amostras e se subtrai a absorbância desta mistura, resultados equivalentes são obtidos em relação a quando se utiliza isooctano puro. Isto está de acordo com o fato de que a absorbância é uma 
propriedade aditiva quando não há, obviamente, interação entre os componentes da solução como é o caso. A absorbância da mistura ISO-ISP 3:2 em relação ao isooctano puro se deve, é claro, à fração de isopropanol da mistura.

A absorbância da mistura ISO-ISP $3: 2$ a $232 \mathrm{~nm}$ utilizada neste trabalho esteve na faixa de 0,100 a 0,120 e portanto, conforme ao método I.U.P.A.C. (1979) que recomenda o uso de isooctano puro adequado à espectrofotometria com transmitâncias acima de 70\% (Absorbância < 0,150) a 220 nm e acima de $90 \%$ (absorbância < 0,050) em 240 nm.

Tabela 5 - Coeficientes de extinção da fração lipídica em função do solvente utilizado para medida da absorbância.

\begin{tabular}{|c|c|c|c|}
\hline & Isooctano & Mistura ISO-ISP 3:2 & $\begin{array}{c}\text { Mistura ISO-ISP 3-2 } \\
\text { corrigido }\end{array}$ \\
\hline & 3,61 & 3,99 & 3,60 \\
\hline & 3,06 & 3,18 & 3,00 \\
\hline & 3,25 & 4,32 & 3,93 \\
\hline Médias & 3,31 & 3,83 & 3,51 \\
\hline
\end{tabular}

* A correção foi feita subtraindo-se a absorbância da mistura ISO-ISP 3:2 das absorbâncias medidas

A análise espectrofotométrica das frações lipídicas depende, obviamente, da presença exclusiva de dienos conjugados (resultantes da hidroperoxidação dos ácidos graxos) como absorventes de luz ultravioleta. Se há a presença de outros compostos que absorvem luz ultravioleta nos comprimentos de onda 
utilizados, esta metodologia não pode ser utilizada. Por este motivo não foi possivel a utilização de agentes antioxidantes como BHA (Butil HidroxiAnisol), BHT (butil hidroxitolueno) ou TBHQ (terc-butil hidroxiQuinona) na extração da fração lipidica a fim de evitar qualquer possibilidade de oxidação adicional.

Estes antioxidantes são derivados do benzeno, o qual absorve fortemente em $184 \mathrm{~nm}$ e em $202 \mathrm{~nm}$ e apresenta uma série de bandas de pequena intensidade na região entre 230 a $270 \mathrm{~nm}$. Quando há a substituição dos hidrogênios do benzeno por grupos que contém elétrons não ligantes como $-\mathrm{OH}$, produz-se um deslocamento bem pronunciado e grande intensificação na absorção (Dyer, 1969). Constatou-se este efeito ao se verificar o aumento da absorbância da mistura isooctanoisopropanol 3:2 quando adicionada de TBHQ na concentração de $0,005 \%(\mathrm{~m} / \mathrm{v})$, que foi de 0,970 , ou seja, a solução com TBHQ absorveu quase $90 \%$ da luz emitida em $232 \mathrm{~nm}$.

\subsection{Efeitos dos tratamentos na fração lipídica dos grãos}

Os efeitos dos tratamentos aplicados aos grãos de soja na fração lipídica dos mesmos foram detectados pela determinação do coeficiente de extinção em $232 \mathrm{~nm}$.

\subsubsection{Grãos íntegros macerados em diferentes temperaturas}

Os grãos de soja foram macerados em cinco diferentes temperaturas acima da ambiente, até que absorvessem a quantidade de água equivalente a 8 horas de 
maceração à temperatura ambiente (bulbo seco $=26^{\circ} \mathrm{C}$ e bulbo úmido $=22^{\circ} \mathrm{C}$ ). Nas condições ambientes, a maceração ocorreu a temperatura de $22{ }^{\circ} \mathrm{C}$, praticamente sem variação durante as 8 horas, pois a evaporação da água para o ambiente manteve a mesma na temperatura de bulbo úmido. Nestas condições, a quantidade de água absorvida após 8 horas de maceração foi de 1,1 vezes o peso inicial, ou seja, a massa de grãos passou de $50 \mathrm{~g}$ para $105 \mathrm{~g}$ aproximadamente. Na Figura 2, que mostra a velocidade de absorção de água pelos grãos, pode-se verificar que os tempos para o aumento dos pesos dos grãos em 1,1 vezes o peso original, foram de $1 \mathrm{~h}$ e $50 \mathrm{~min}$ a $50^{\circ} \mathrm{C}$, $1 \mathrm{~h}$ e $20 \mathrm{~min}$ a $60{ }^{\circ} \mathrm{C}, 52 \min$ a $70{ }^{\circ} \mathrm{C}, 33 \min$ a $80^{\circ} \mathrm{C}$ e, $28 \min$ a $98^{\circ} \mathrm{C}$.

A Figura 4 apresenta os resultados obtidos para o coeficiente de extinção da fração lipídica de grãos íntegros macerados em água nas temperaturas e tempos dados acima e depois liofilizados. O coeficiente de extinção obtido para a fração lipídica de grãos macerados em água a temperatura ambiente foi de 5,88 , valor intermediário entre os obtidos para a fração lipídica de grãos não macerados que foi de 3,4 [extraído pelo método de Hara \& Radin (1978) modificado] e a de grãos triturados e adicionados de água que foi de 8,92 (ítem 5.3). Portanto, há a formação de dienos conjugados no processo de maceração de grãos íntegros, e portanto, ocorre realmente a oxidação da fração lipídica na maceração. Era de se esperar que o nível de oxidação da fração lipídica de grãos íntegros fosse menor que a de grãos triturados e adicionados de água, pois nestes tanto as lipoxigenases como seus substratos encontram-se descompartimentalizados. 


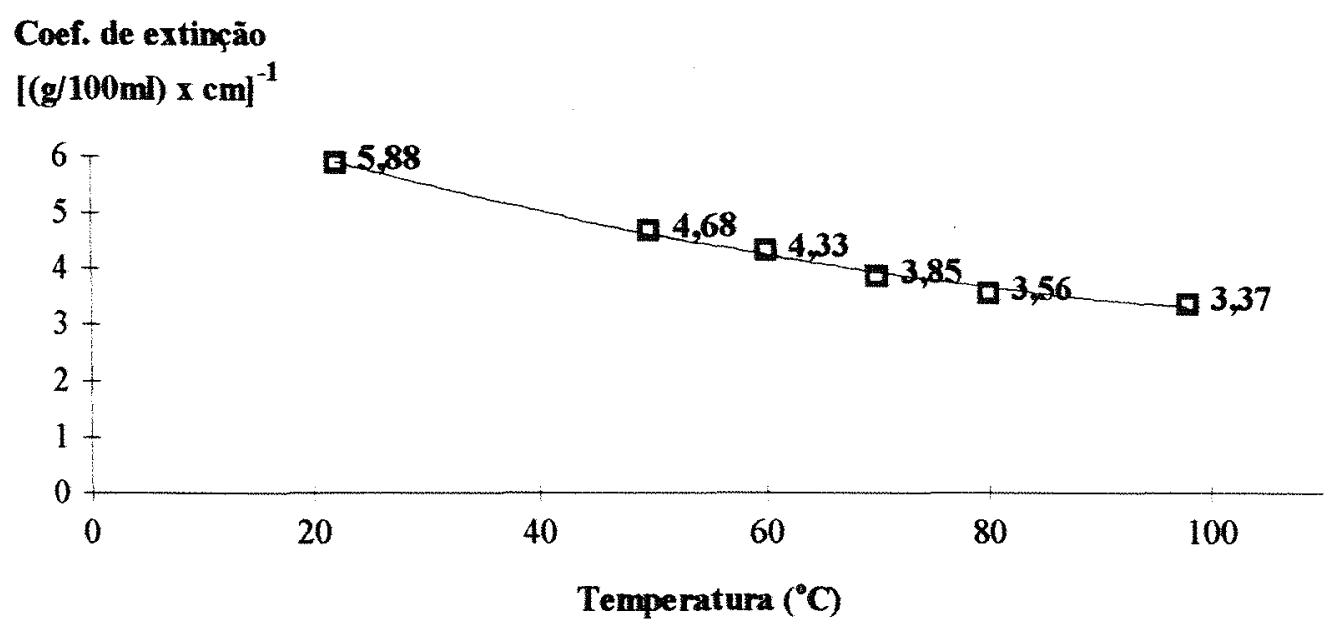

Figura 4 - Coeficientes de extinção da fração lipídica de grãos macerados em água em diferentes temperaturas e liofilizados.

A aplicação do teste de Dunnett permitiu concluir que os valores de coeficiente de extinção obtidos para a fração lipídica de grãos macerados em temperaturas acima de $70{ }^{\circ} \mathrm{C}$ (Figura 4) não diferem $(\mathrm{p}<0,05)$ do de grãos não macerados $(3,40)$, indicando a ausência de atividade oxidativa em condições de temperatura superiores a esta. Wilkens et al. (1967) verificaram que na trituração de grãos de soja com água, a temperatura mínima para que não houvesse formação de compostos voláteis, responsáveis pelo flavor desagradável, foi $80{ }^{\circ} \mathrm{C}$. Baker \& Mustakas (1973) alcançaram a completa inativação das lipoxigenases após 15 minutos de cozimento em água a $82{ }^{\circ} \mathrm{C}$; a $49{ }^{\circ} \mathrm{C}$ não ocorreu inativação. Rice et al. (1981) chegaram à completa inativação das lipoxigenases de grãos íntegros com umidade de $8 \%$, após aproximadamente 3 minutos de aquecimento a $100{ }^{\circ} \mathrm{C}$ com vapor vivo à pressão 
atmosférica. Brown et al. (1982) apresentaram procedimento para inativação térmica das lipoxigenases dos cotilédones da soja sem perda da solubilidade das proteínas. $O$ procedimento consistia em ajustar o conteúdo de umidade dos cotilédones para o valor de $16,3 \%$ com um tampão de $\mathrm{KOH} / \mathrm{NaHCO}_{3}, \mathrm{pH}=9,8$, e aquecer com vapor por aproximadamente 10 segundos. Nas temperaturas superiores a $91{ }^{\circ} \mathrm{C}, 99 \%$ das lipoxigenases podem ser inativadas com manutenção de solubilidade de proteínas acima de $70 \%$. Hildebrand \& Kito (1984) estudando a inativação térmica de cada isoenzima, verificaram que $20 \mathrm{~min}$ a $70^{\circ} \mathrm{C}$ foi suficiente para inativar completamente as L-2 e L-3 nos extratos crús, sendo necessários 120 min para inativá-las completamente, inclusive a L-1. Engeseth et al. (1987) verificaram que as isoenzimas lipoxigenases de farinhas de soja não foram completamente inativadas após 3 horas à $67^{\circ} \mathrm{C}$.

Enfim, demonstrou-se (Farkas \& Goldblith, 1962; Rice et al., 1981; Paula et al., 1995) que a inativação térmica das lipoxigenases, bem como a insolubilização das proteinas, pode ser descrita como uma reação de primeira ordem, ou seja, a taxa de atividade da enzima diminui exponencialmente com o tempo de aquecimento.

$O$ coeficiente de extinção (E) da fração lipídica dos grãos macerados diminuiu com a temperatura de maceração e a equação polinomial de $2^{a}$ ordem (Figura 4), expressa por $E=0,0003 T^{2}-0,0646 T+7,2095\left(R^{2}=0,9923\right)$ se ajustou bem aos dados.

Rice et al. (1981) estudaram o efeito do conteúdo de umidade de grãos integros na inativação das lipoxigenases a $100{ }^{\circ} \mathrm{C}$ e constataram que o tempo para a inativação reduz lentamente com o aumento da umidade até $18 \%$, e que acima deste 
valor, diminui rapidamente. Este dado se faz pertinente neste ponto, uma vez que quanto maior a temperatura, mais rápida é a absorção de água (Figura 2) e, com mais água, mais rápida é a inativação das lipoxigenases.

Estes resultados demonstram que o método utilizado neste trabalho permite a verificação da ação das lipoxigenases através da análise espectrofotométrica de dienos conjugados na fração lipídica.

\subsubsection{Grãos íntegros aquecidos em microondas e macerados em água}

A Figura 5 apresenta as temperaturas finais médias observadas ao final do aquecimento no forno de microondas para os vários tempos de exposição testados. $\mathrm{O}$ comportamento obtido (forma da curva) é idêntico ao obtido por Pour-El et al. (1981), ou seja, a curva da temperatura em função do tempo de exposição às microondas obedece a uma equação polinomial de segunda ordem. Apesar disso, as temperaturas alcançadas pelos grãos neste trabalho foram intermediárias entre os valores obtidos pelo mesmo autor e as obtidas por Wang \& Toledo (1987) para os mesmos tempos de exposição. Por exemplo, após 120 segundos de aquecimento, observa-se na Figura 5 que os grãos alcançaram $132,5^{\circ} \mathrm{C}$, enquanto Pour-El et al. (1981) obtiveram $190^{\circ} \mathrm{C}$ para grãos de cultivar americano não especificado com umidade de 7,6 \% e Wang \& Toledo (1987) obtiveram apenas $80^{\circ} \mathrm{C}$ para grãos do cultivar Santa Rosa com umidade de $8,7 \%$. 


\section{Temperatura}

$\left({ }^{\circ} \mathrm{C}\right)$

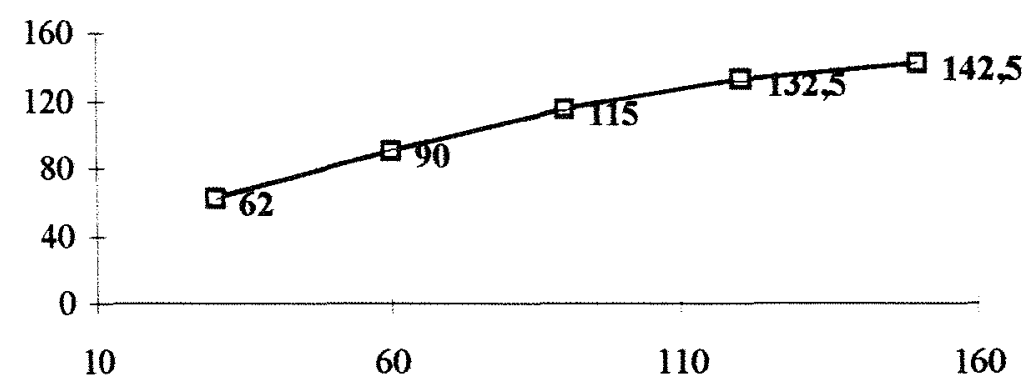

Tempo de aquecimento (s)

Figura 5 - Curva de aquecimento de grãos de soja em forno de microondas

Embora a frequência dos microondas utilizados nesses trabalhos tenha sido a mesma, $2450 \mathrm{MHz}$, estas discrepâncias podem ser atribuídas às diferenças de operação e, principalmente, à quantidade de amostra utilizada por ensaio e à potência fornecida pelo microondas. Wang \& Toledo (1987) utilizaram $150 \mathrm{~g}$ por ensaio, como neste trabalho, enquanto Pour-El et al. (1981) utilizaram $225 \mathrm{~g}$. Neste trabalho, operouse o forno de microondas na potência de $800 \mathrm{~W}$.

A perda de água também aumenta com o tempo de aquecimento no forno de microondas. A Figura 6 apresenta a perda percentual de água em função do tempo de aquecimento no forno de microondas. 


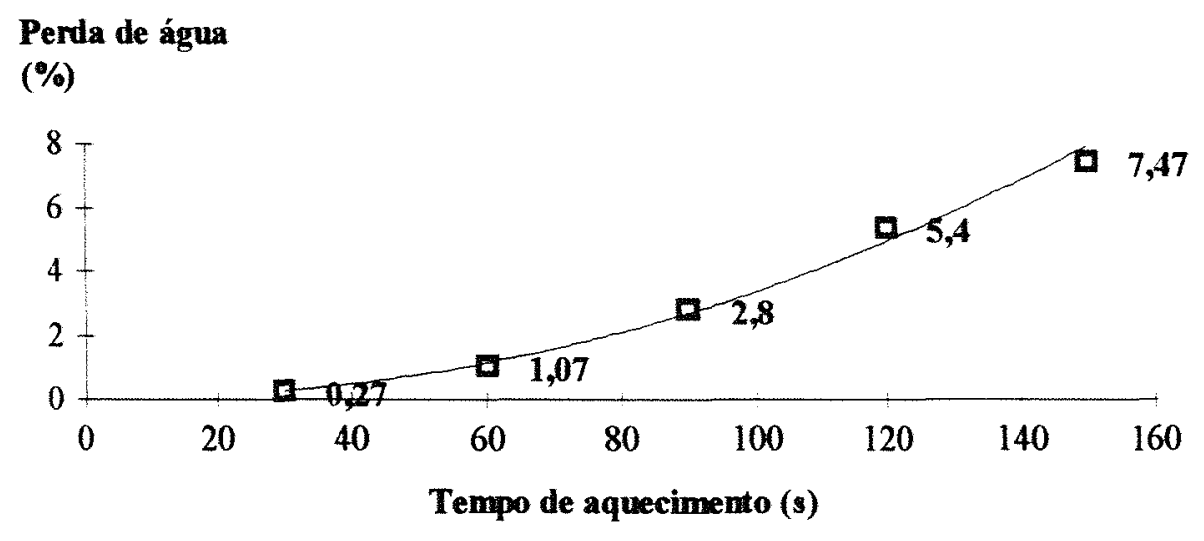

Figura 6 - Perda de água de grãos aquecidos em forno de microondas

Pour-El et al. (1981) utilizaram a energia absorvida como um indicador do efeito do aquecimento no forno de microondas e atribuíram a absorção de energia pelos grãos, durante o aquecimento dielétrico, a dois processos principais, ao aumento da temperatura dos grãos e à vaporização de água dos mesmos. Eles calcularam a energia mínima absorvida por grama ("minimum energy absorbed per gram" - MEA) a partir dos dados de temperatura e perda de umidade e, considerou as expressões, $c_{p}=0,39123+0,0046057 \mathrm{M}$, para o calor específico e, $h_{v}=539\left(1+0,21624 \mathrm{e}^{-0,06233 \mathrm{M}}\right)$ para o calor de vaporização da água contida nos grãos, onde $M$ é a umidade dos grãos na base seca. A energia mínima absorvida foi determinada pela fórmula: $M E A=c_{p} \Delta T+h_{v} \Delta M$, onde $\Delta \mathrm{T}$ é o aumento de temperatura e $\Delta \mathrm{M}$ é a perda percentual de umidade (base seca). Analisando a atividade das lipoxigenases em função da energia mínima absorvida verificaram que para o valor de $150 \mathrm{cal} / \mathrm{g}$, mais de $90 \%$ da atividade original foi perdida, o que significaria uma melhoria do "flavor" dos produtos dos grãos tratados desta forma. 
Para MEA próximos de $100 \mathrm{cal} / \mathrm{g}$, mais que $60 \%$ da atividade original seria perdida. A partir dessas fórmulas e dos dados de temperatura (Figura 5) e de perda de água (Figura 6) obtidos neste trabalho obteve-se os valores indicados na Tabela 6 .

Tabela 6 - Energia mínima absorvida (MEA) pelos grãos de soja no aquecimento em forno de microondas

\begin{tabular}{cccc}
\hline Tempo (s) & $\Delta \mathrm{M}(\%)^{\mathrm{i}}$ & $\Delta \mathrm{T}\left({ }^{\circ} \mathrm{C}\right)^{2}$ & $\mathrm{MEA}(\mathrm{cal} / \mathrm{g})^{3}$ \\
\hline 30 & 0,30 & 42 & 20 \\
60 & 1,17 & 70 & 38 \\
90 & 3,08 & 95 & 60 \\
120 & 5,94 & 112 & 85 \\
150 & 8,21 & 122 & 103 \\
& & & \\
\hline${ }^{1}$ Base seca & & \\
${ }^{2}$ Temperatura inicial $=20^{\circ} \mathrm{C}$ \\
${ }^{3} \mathrm{c}_{\mathrm{p}}=0,44 \mathrm{cal} / \mathrm{g}{ }^{\circ} \mathrm{C} \mathrm{e}, \mathrm{h}_{\mathrm{r}}=602 \mathrm{cal} / \mathrm{g}$
\end{tabular}

Como se pode observar, os tratamentos realizados neste trabalho não permitiram chegar a valores de energia mínima absorvida pelos grãos próximos a 150 cal/g mas, houve aumento contínuo com o tempo de exposição e, com 150 segundos de aquecimento, ultrapassou $100 \mathrm{cal} / \mathrm{g}$. A aplicação do teste de Dunnett permitiu concluir que os valores de coeficiente de extinção obtidos para a fração lipídica de grãos aquecidos por mais que 60 segundos (Figura 7) não diferem entre si $(p<0,05 \%)$ e, como 
são inferiores ao de grãos não macerados, concluiu-se que não houve ocorrência de oxidação em grãos aquecidos além deste tempo.

A equação polinomial de segunda ordem $E=0,0001 t^{2}-0,0376 t+5,5443$ $\left(R^{2}=0,9515\right)$, ajustou-se bem aos valores experimentais de coeficiente de extinção (E) em função do tempo de aquecimento $(t)$ no forno de microondas.

Após tratamento por 240 segundos de grãos com $8,7 \%$ de umidade, Wang \& Toledo (1987) detectaram uma atividade residual das lipoxigenases de $2,3 \%$ com temperatura de $122,3^{\circ} \mathrm{C}$. A Figura 5 mostra que temperaturas dessa mesma ordem de grandeza foram obtidas com 90 segundos de tratamento e que, portanto, residuais baixos de atividade das lipoxigenases devem ser esperados, o que se confirma pelos resultados apresentados na Figura 7.

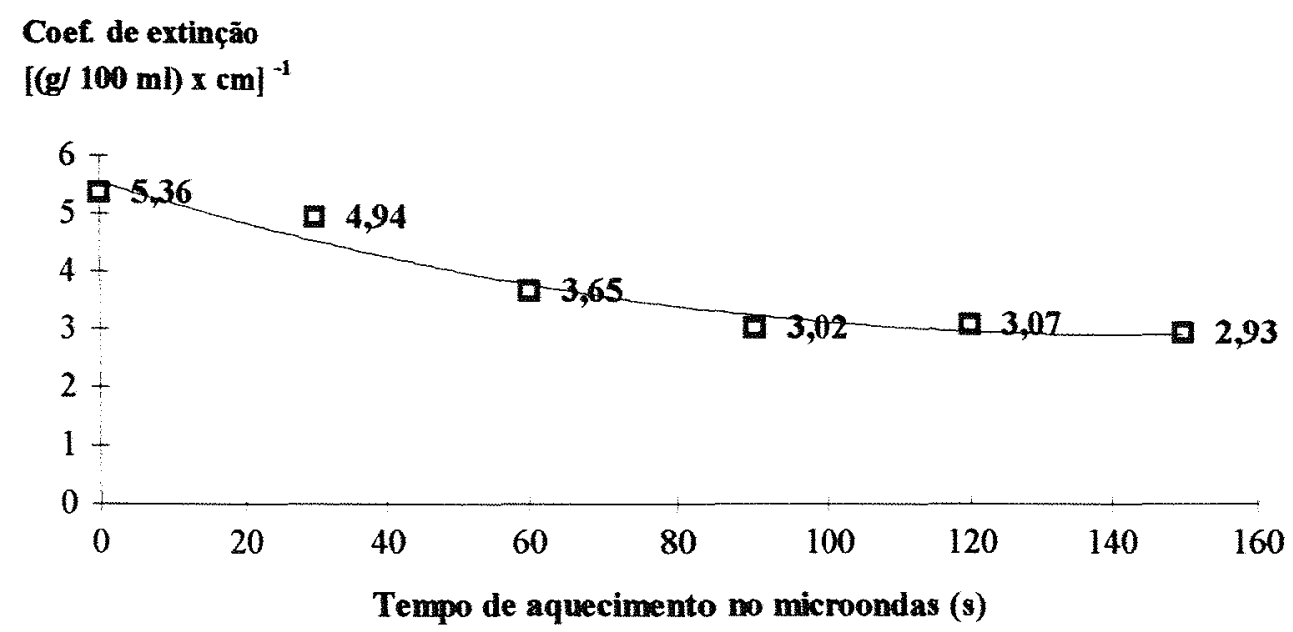

Figura 7 - Coeficiente de extinção da fração lipídica de grãos aquecidos em forno de microondas, macerados em água e liofilizados. 


\subsubsection{Grãos íntegros macerados em diferentes soluções}

A escolha das soluções de maceração baseou-se nos trabalhos encontrados na literatura (ítem 3.3) que visaram a inativação das lipoxigenases ou a melhoria do "flavor" dos produtos da soja. Optou-se pelas concentrações de maior eficiência. Muitos trabalhos estudaram os efeitos combinados dessas soluções com outros processos como os que fazem uso de energia térmica, porém, aqui, analisamos os efeitos das macerações apenas com as soluções à temperatura ambiente por 8 horas.

A Figura 8 apresenta os coeficientes de extinção da frações lipídicas extraídas dos grãos íntegros macerados à temperatura ambiente em diversas soluções. Nenhuma das soluções de maceração estudadas impediu a ocorrência da oxidação, uma vez que o coeficiente de extinção das frações lipídicas dos grãos em todos os tratamentos foi superior ao dos grãos não macerados, de 3,40 .

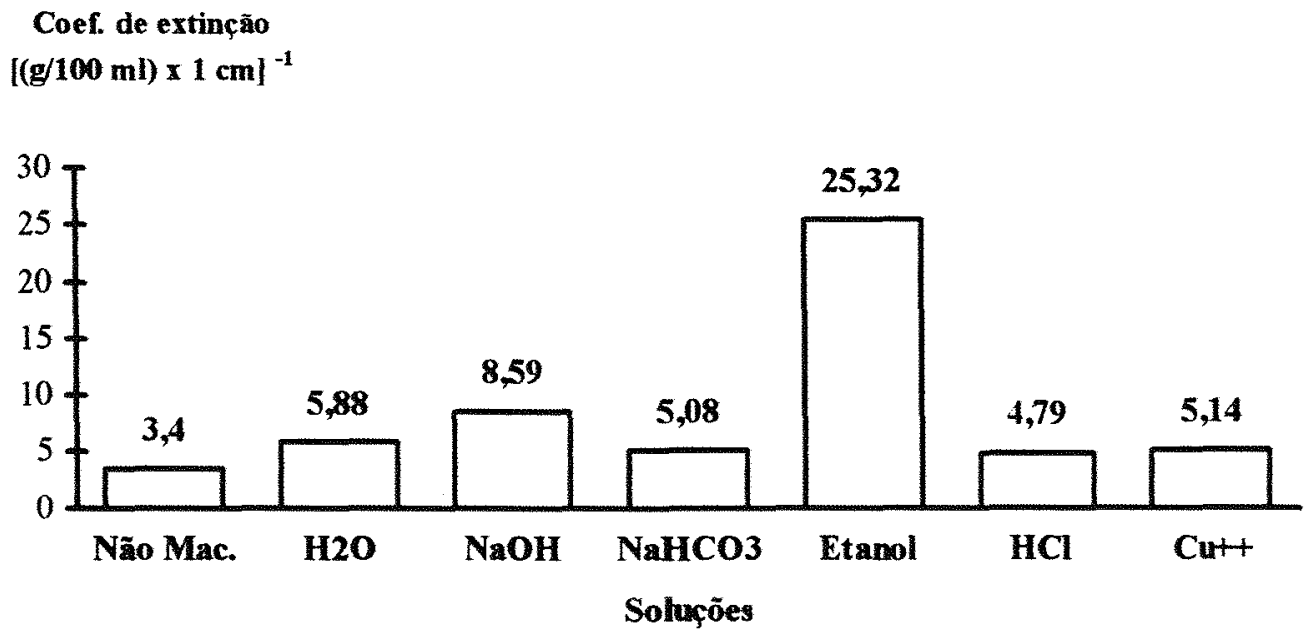

Figura 8 - Coeficiente de extinção da fração lipídica de grãos íntegros macerados em diversas soluçōes e liofilizados. 
Pela aplicação do teste de Tukey $(p<0,05 \%)$ verificou-se que os coeficientes de extinção da fração lipídica dos grãos macerados em soluções de $\mathrm{NaOH}$ e de etanol foram maiores do que dos grãos macerados em água e nas outras soluções, enquanto que os destas não diferiram significativamente entre si. Todas as soluções resultaram em coeficiente de extinção superior aos dos grãos não tratados, ou seja, nenhuma delas inibiu a atuação das lipoxigenases.

Para tentar explicar os valores altos das macerações em $\mathrm{NaOH}$ e em etanol, considerou-se a possibilidade de ocorrência de reações adversas que levariam à formação de compostos que absorvem luz ultravioleta na região de $232 \mathrm{~nm}$ e o fato de que tais soluções poderiam promover a extração de outros compostos com as mesmas propriedades ou ainda, que as soluções utilizadas para a maceração (Tabela 7) poderiam conter esses mesmos compostos. No caso da solução de hidróxido de sódio, Badenhop \& Hackler (1970), conforme apresentado no ítem 3.3, recomendaram a maceração prévia dos grãos em solução $0,05 \mathrm{~N}$ por 2 horas a $50^{\circ} \mathrm{C}$, e mencionaram a formação de niacina em milho macerado em soluções de $\mathrm{NaOH}$. Neste trabalho, como os grãos de soja foram macerados por $8 \mathrm{~h}$, a possibilidade de se ter formado niacina é grande, e esta é uma vitamina que possui estrutura análoga à do benzeno (ítem 3.3) e que deve portanto, absorver muita luz ultravioleta conforme visto no ítem 5.3.

No caso da maceração em solução etanólica e sua alta absorbância, a possibilidade mais provável é a do álcool utilizado para o preparo da solução conter compostos que absorvessem luz na região do ultravioleta, uma vez que, este álcool fora obtido de indústria local, que utiliza ciclohexano comercial, que deve conter muitas 
impurezas, no processo de desidratação. Contudo, na Tabela 7 , se apresentam as absorbâncias das soluções utilizadas nas macerações, onde a solução etanólica, embora tenha a maior absorbância, ela não é significativamente diferente das outras. Julgou-se que estudos adicionais são necessários para explicar o fato em questão.

Tabela 7 - Absorbâncias das soluções de maceração em relação à água destilada

Solução

Água (comercial)

$\mathrm{NaOH} 0,05 \mathrm{~N}$

$\mathrm{NaHCO}_{3} 0,05 \%(\mathrm{~m} / \mathrm{v})$

Etanol $15 \%(\mathrm{v} / \mathrm{v})$

$\mathrm{HCl} 0,30 \mathrm{M}$

$\mathrm{Cu}^{2+} 12 \mathrm{ppm}$
Absorbância em $232 \mathrm{~nm}$

0,065

0,043

0,091

0,037

0,082

O fato das soluções utilizadas não evitarem a oxidação da fração lipídica dos grãos na maceração poderia ser explicado da seguinte forma. Nas reações de oxidação catalisadas pelas lipoxigenases há uma afinidade muito grande entre as enzimas e seus substratos de modo que são muito rápidas ou, pelo menos, muito mais rápidas do que a atuação dos compostos destas soluções na inativação das lipoxigenases ou no mecanismo de atuação destas. Assim, quando se completaria a inativação das lipoxigenases, estas já teriam atuado na oxidação da fração lipídica. As melhorias relatadas na literatura deveriam-se muito mais a outras formas de atuação destas soluções do que à inibição do processo de oxidação. É importante informar que embora não tenha sido objetivo deste estudo, observou-se a formação de odores peculiares nas macerações 
com as diferentes soluções, distintos dos das soluções isoladamente, bastante evidentes com etanol e com $\mathrm{HCl}$.

Talvez a atuação dos compostos destas soluções seja mais eficiente, por exemplo, em temperaturas mais elevadas, o que explicaria o fato de que vários procedimentos combinados com tratamentos térmicos (Brown et al., 1982; Nelson et al., 1976; Baker \& Mustakas, 1973) tenham obtido sucesso na inibição das lipoxigenases ou na melhoria do "flavor" dos produtos.

\subsubsection{Grãos triturados e adicionados de diferentes soluções}

Como se mostrou no ítem 3.2 , a adição de água a grãos triturados (farinha de soja) deve promover ainda mais a atuação das lipoxigenases sobre a fração lipídica uma vez que a trituração provoca a descompartimentalização das lipoxigenases e de seus substratos e a adição de água permite a ativação das lipoxigenases e a oxidação dos ácidos graxos.

No ítem 5.3 apresentaram-se os resultados obtidos para os índices de peróxidos e coeficientes de extinção dos óleos brutos (1,84 e 3,05, respectivamente) e oxidado $(5,5$ e 8,92 , respectivamente) com os quais se demonstrou a ocorrência da oxidação e também a utilidade do método espectrofotométrico no seu acompanhamento.

O objetivo do procedimento no presente ítem foi promover a oxidação da fração lipídica de grãos triturados adicionados das diversas soluções também estudadas no ítem anterior (5.4.3), nas condições ambientes. 
É importante colocar que, não se pretendeu aqui, determinar a atividade das enzimas lipoxigenases, para o que seria necessário utilizar-se de procedimentos já bem estabelecidos para este fim, com substratos puros e controle das condições como $\mathrm{pH}$, temperatura, etc. Aqui, enzima e substrato encontravam-se na forma natural, com a presença de muitos outros compostos, dentre eles, antioxidantes naturais, além de não se ter controlado $\mathrm{pH}$ nem temperatura. As soluções foram preparadas sempre com a mesma água obtida no comércio local e a temperatura permaneceu praticamente constante durante os experimentos.

A Figura 9 apresenta os resultados dos coeficientes de extinção das frações lipidicas extraídas de grãos triturados adicionados das várias soluções.

Não foi possivel apontar qual das soluções foi mais eficiente no impedir a atuação das lipoxigenases, se é que há tal impedimento neste processo. Curvas exponenciais, do tipo $\mathrm{E}=\mathrm{A}[1-\exp (\mathrm{B}-\mathrm{Ct})]$, foram as que melhor se ajustaram aos dados experimentais de modo geral, porém, as curvas diferiram muito entre si e os coeficientes de determinação $\left(R^{2}\right)$ variaram entre 0,81 (para a água) e 0,96 (para a solução de $\mathrm{Cu}^{2+}$ ). $\mathrm{O}$ parâmetro A das equações representa o valor para o qual tende o coeficiente de extinção. Para a solução de etanol $15 \%$, obteve-se o maior valor para A, igual a 12,161 , enquanto para a solução de $\mathrm{HCl} 0,30 \mathrm{M}$ obteve-se o menor valor, igual a 5,321. Para as soluções de $\mathrm{NaHCO}_{3}, \mathrm{NaOH}, \mathrm{Cu}^{2+}$ e $\mathrm{H}_{2} \mathrm{O}$ os valores de $\mathrm{A}$ foram 7,371, 6,440, 6,489 e, 6,043 , respectivamente. Estas tendências concordam parcialmente com os resultados obtidos no ítem anterior. 


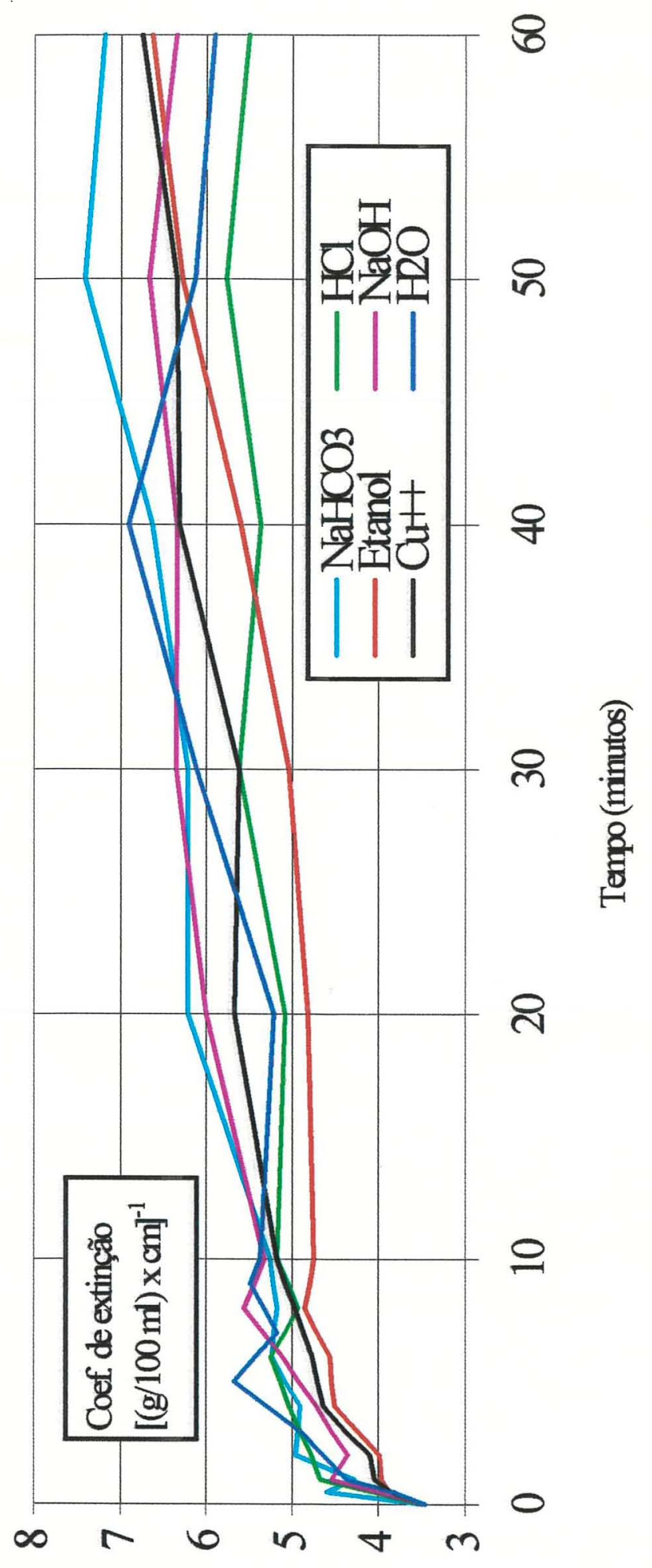

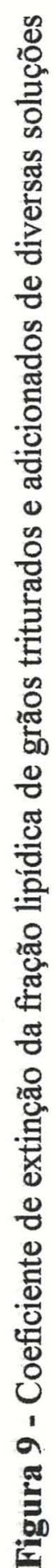


Percebe-se um aumento substancial do coeficiente de extinção nos primeiros 10 minutos e depois uma tendência de aumento mais lento. Em grãos triturados, misturados com água destilada por uma hora e depois liofilizados, conforme já discutido, obteve-se coeficiente de extinção de 8,92. As frações lipídicas dos grãos, neste caso, foram extraídas em extratores tipo Butt e depois secas em estufa a $105^{\circ} \mathrm{C}$, o que pode ter provocado mais oxidação. A presença de água na amostra deve ter interferido na extração ou na análise da fração lipídica, pois os valores obtidos de coeficientes de extinção da fração lipidica depois de uma hora de mistura, não coincidem com a apresentada no ítem 5.3 onde os grãos foram liofilizados antes da extração. Os valores dos coeficientes de extinção da fração lipídica após uma hora de mistura variaram entre 5,5 e 7,3 , bem menores que 8,92 , referido anteriormente. Também aqui, julga-se necessária a realização de pesquisas adicionais para a melhor elucidação dos fatos. 


\section{CONCLUSÕES}

Para os grãos íntegros macerados e liofilizados, o método de extração da fração lipídica utilizado com as modificações introduzidas, satisfez perfeitamente as condições necessárias para que se alcançassem os objetivos propostos, ou seja, permitiu a rápida extração da fração lipídica de forma quantitativa em condições de baixa susceptibilidade à oxidação.

O método de análise da fração lipídica utilizado permite a detecção da oxidação sofrida pela fração lipídica no processo de maceração, desde que nesta não existam outros compostos que absorvam luz na região do ultravioleta.

Para os grãos macerados acima da temperatura ambiente e para aqueles tratados em fornos de microondas, as análises espectrofotométricas da fração lipídica permitiram observar, de forma bastante evidente, o nível de atuação das lipoxigenases e, portanto, o nível de oxidação (pelo menos relativo) sofrido pela fração lipidica. 
Quanto maior a temperatura de maceração, menor o tempo necessário para a mesma e menor a oxidação sofrida pela fração lipídica dos grãos; quanto maior o tempo de aquecimento dos grãos no forno de microondas, menor a ocorrência de oxidação durante a maceração.

A maceração de grãos nas soluções e condições estudadas (à temperatura ambiente) não impediu a atuação das lipoxigenases sobre a fração lipídica. 


\section{REFERÊNCIAS BIBLIOGRÁFICAS}

A.O.A.C. - ASSOCIATION OF OFFICIAL ANALYTICAL CHEMISTS - Official methods of analysis, $11^{\mathrm{a}} \mathrm{ed}$., Washington, 1970.

A.O.C.S. - AMERICAN OIL CHEMISTS' SOCIETY - Official methods and recommended practices, $4^{\mathrm{a}}$ ed., Champaign, 1991.

ASHRAF, H.R.L.; SNYDER, H.E. Influence of ethanolic soaking of soybeans on flavor and lipoxygenase activity of soymilk. Journal of Food Science, v.46, p.1201-1204, 1981.

AXELROD, B.; CHEESBROUGH, T.M.; LAAKSO, S. Lipoxygenase from soybeans. In: LOWENSTEIN, J.M., (Ed.) Methods in enzymology. New York: Academic Press, 1981. v.71, p.441-451.

BADENHOP, A.F.; HACKLER, L.R. Effects of soaking soybeans in sodium hydroxide solution as pretreatment for soy milk production. Cereal Science Today, v.15, n.3, p.84-88, mar. 1970.

BADENHOP, A.F.; WILKENS, W.F. The formation of 1-0-1-octen-3-ol in soybeans during soaking. Journal of the American Oil Chemists' Society, v.46, p.179, 1969. 
BAKER, E.C.; MUSTAKAS, G.C. Heat inactivation of trypsin inhibitor, lipoxygenase and urease in soybeans: effect of acid and base additives. Journal of the American Oil Chemists' Society, v.50, p.137-141, maio 1973.

BARROS, E.G.; MOREIRA, M.A.; FONTES, E.P.B. Atividades de lipoxigenases $L_{1}$ e $\mathrm{L}_{3}$ em cultivares comerciais de soja. Arquivos de Biologia e Tecnologia, v.27, n.3, p.381-386, 1984.

BEWLEY, J.D.; BLACK, M. Seeds - physiology of development and germination. $2^{\underline{a}}$ ed. N.Y., London: Plenum Press, 1994. 445p.

BLIGH, E.G.; DYER, W.J. A rapid method of total lipid extraction and purification. Canadian Journal of Biochemistry and Physiology. v. 37, n.8, p.911-917, ago. 1959.

BORHAN, M.; SNYDER, H.E. Lipoxygenase destruction in whole soybeans by combinations of heating and soaking in ethanol. Journal of Food Science, v.44, n.2, p.586-590, 1979.

BOURNE, M.C.; ESCUETA, E.E.; BANZON, J. Effect of sodium alkalis and salts on pH and flavor of soymilk. Journal of Food Science, v.41, p.62-66, 1976.

BRASIL. Ministério da Saúde. Divisão Nacional de Vigilância Sanitária de Alimentos. Comissão Nacional de Normas e Padrões para Alimentos - C.N.N.P.A. - Resolução $\mathrm{N}^{\mathrm{o}}$ 22/77. In: ASSOCIAÇÃO BRASILEIRA DAS INDÚSTRIAS DE ALIMENTAÇÃO - ABIA. Compêndio da legislação de alimentos. São Paulo, 1981. v.1/A, p.7.10-7.14. 
BROWN, B.D.; WEI, L.S.; STEINBERG, M.P.; VILOTTA, R. Minimizing protein insolubilization during thermal inactivation of lipoxygenase in soybean cotyledons. Journal of the American Oil Chemists' Society, v.59, n.2, p.88-92, fev. 1982.

CHE MAN, Y.B.; WEI, L.S.; NELSON, A.I. Acid inactivation of soybean lipoxygenase with retention of protein solubility. Journal of Food Science, v.54, n.4, p.963-967, 1989.

CHE MAN, Y.B.; WEI, L.S.; NELSON, A.I.; YAMASHITA, N. Effects of soaking soybeans in dilute acids on biologically active components. Journal of the American Oil Chemists' Society, v.68, n.7, p.471-473, jul. 1991.

CHEN, I.S.; SHEN, C.S.J.; SHEPPARD, A.J. Comparison of methylene chloride and chloroform for the extraction of fats from food products. Journal of the American Oil Chemists' Society, v.58, p.599-601, maio 1981.

DE LA ROCHE, I.A.; ANDREWS, C.J. Changes in phospholipid composition of a winter wheat cultivar during germination at $2 \mathrm{C}$ and $24 \mathrm{C}$. Plant Physiology, v.51, p.468-473, 1973.

DYER, J.R. Aplicações da espectrofotometria da absorção dos compostos orgânicos. Trad. de A. G. Albanese. São Paulo: Edgard Blücher, EDUSP, 1969. $155 \mathrm{p}$.

ENGESETH, N.J.; KLEIN, B.P.; WARNER, K. Lipoxygenase isoenzymes in soybeans: effects on crude oil quality. Journal of Food Science, v.52, n.4, p.1015-1019, 1987.

EWING, G.W. Métodos instrumentais de análise química. Trad. de A. G. Albanese e J.T. S. Campos. São Paulo: Edgard Blücher, EDUSP, 1972. 
FARKAS, D.F.; GOLDBLITH, S.A. Studies on the kinetics of lipoxidase inactivation using thermal and ionizing energy. Journal of Food Science, v.27, p.262-276, 1962.

FOLCH, J.; ASCOLI, I.; LEES, M.; MEATH, J.A.; LeBARON, F.N. Preparation of lipid extracts from brain tissue. Journal of Biological Chemistry, v.191, p.833841,1951 .

FOLCH, J.; LEES, M.; STANLEY, G.H.S. A simple method for the isolation and purification of total lipides from animal tissues. Journal of Biological Chemistry, v.226, p.497-509, 1957.

FRANKEL, E.N. Chemistry of autoxidation: mechanism, products and flavor significance. In: MIN, D.B.; SMOUSE, T.H. (Ed.) Flavor chemistry of fats and oils. Champaign: American Oil Chemists'Society, 1985. cap.1, p.1-37.

GARDNER, H.W. Decomposition of linoleic acid hydroperoxides. Enzymic reactions compared with nonenzymic. Journal of Agriculture and Food Chemistry, v.23, n.2, p.129-135, 1975.

GARDNER, H.W. Lipid hydroperoxide reactivity with proteins and amino acids: a review. Journal of Agriculture and Food Chemistry, v.27, n.2, p.220-229, 1979.

GARDNER, H.W. How the lipoxygenase pathway affects the organoleptic properties of fresh fruit and vegetables. In: MIN, D.B.; SMOUSE, T.H. (Ed.) Flavor chemistry of lipid foods. Champaign: American Oil Chemists'Society, 1989. cap.6, p.98-112.

GRAY, J.I. Measurement of lipid oxidation: a review. Journal of the American Oil Chemists' Society, v.55, p.539-546, jun. 1978. 
GRAY, J.I. Simple chemical and physical methods for measuring flavor quality of fats and oils. In: MIN, D.B.; SMOUSE, T.H. (Ed.) Flavor chemistry of fats and oils. Champaign: American Oil Chemists'Society, 1985. cap.12, p.223-239.

HARA, A.; RADIN, N. S. Lipid extration of tissues with a low-toxicity solvent. Analytical Biochemistry, v.90, p.420-426, 1978.

HILDEBRAND, D.F.; KITO, M. Role of lipoxygenases in soybean seed protein quality. Journal of Agriculture and Food Chemistry, v.32, n.4, p.815-819, 1984.

HÜHN, S. Efeito do íon cúprico no sabor do "leite de soja". Viçosa, 1977. 42p. Dissertação (M.S.) - Universidade Federal de Viçosa.

INSTITUTO ADOLFO LUTZ - Normas analíticas do Instituto Adolfo Lutz: Métodos químicos e físicos para análise de alimentos. $3^{\underline{a}}$ ed. São Paulo: IAL, 1985. v.1, 533p.

I.U.P.A.C. - INTERNATIONAL UNION OF PURE AND APPLIED CHEMISTRY Standard methods for the analysis of oils, fats and derivatives. $6^{\mathrm{a}}$ ed. Oxford: Pergamon Press, 1979. 170p.

KATES, M. Lipid extraction procedures. In: KATES, M. Techniques of lipidology isolation, analysis and identification of lipids. London: Elsevier Applied Science, 1986. cap.3, p. 100-111.

KHOR, H.T; CHAN, S.L. Comparative studies of three solvent mixtures for the extraction of soybean lipids. Journal of the American Oil Chemists' Society, v.62, n. 1, p.98-99, jan. 1985. 
LUMLEY, I.D.; COLWELL, R.K. Extraction of fats from fatty foods and determination of fat content. In: ROSSELL, J.B.; PRITCHARD, J.L.R. Analysis of oilseeds, fats and fatty foods. London: Elsevier Applied Science, 1991. cap. 6, p.227-259.

MANDARINO, J.M.G.; CARRÃO-PANIZZI, M.C.; OLIVEIRA, M.C.N. Chemical composition of soybean seeds from different production areas of Brazil. Arquivos de Biologia e Tecnologia, v. 35, n. 4, p. 647-653, dez. 1992.

NELSON, J.G. Isolation and purification of lipids from biological matrices. In: PERKINS, E.G. (Ed.) Analyses of fats, oils and lipoproteins. Champaign: AOCS - American Oil Chemists' Society, 1991. cap.2, p.20-59.

NELSON, A.I.; STEINBERG, M.P.; WEI, L.S. Illinois process for preparation of soymilk. Journal of Food Science, v.41, p.57-61, 1976.

PAULA, A.C.O. de; CARVALHO Jr., I.C.; CABRAL, L.C.; VIEIRA, C.R.; BASTOS, A.M.M. Estudo cinético da inativação térmica da lipoxigenase e da insolubilização protéica na soja. Ciência e Tecnologia de Alimentos, v.15, n.3, p.262-267, dez. 1995.

POUR-EL, A.; NELSON, S.O; PECK, E.E.; TJHIO, B.; STETSON, L.E. Biological properties of VHF- and microwave-heated soybeans. Journal of Food Science, v. 46, p. $880-885 ; 895,1981$.

RACKIS, J.J.; SESSA, D.J.; HONIG, D.H. Flavor problems of vegetable food proteins. Journal of American Oil Chemists' Society, v. 56, p. 262-271, mar. 1979. 
RADIN, N.S. Extraction of tissue lipids with a solvent of low toxicity. In: LOWENSTEIN, J.M., (Ed.) Methods in enzymology. New York: Academic Press, 1981. v.72, parte D, p.5-7.

RICE, R.D.; WEI, L.S.; STEINBERG, M.P.; NELSON, A.I. Effect of enzyme inactivation on the extracted soybean meal and oil. Journal of the American Oil Chemist's Society, v.58, p.578-583, maio 1981.

ROBERTSON, J.A.; MORRISON, W.H.; BURDICK, D. Chemical evaluation of oil from field- and storage - damaged soybeans. Journal of the American Oil Chemists' Society, v.50, n.11, p.443-445, 1973.

SIEDOW, J.N. Plant lipoxygenase: structure and function. Annual Review Plant Physiology Molecular Biology, v.42, p. 145-188, 1991.

SONG, Y. ; LOVE, M. H.; MURPHY, P. Subcellular localization of lipoxygenase-1 and -2 in germinating soybean seeds and seedlings. Journal of the American Oil Chemists' Society, v.67, n.12, p.961-965, dez. 1990.

STEEL, R.G.D.; TORRIE, J.H. Principles and procedures of statistics - a biometrical approach. $2^{a}$ ed. Singapura: McGraw-Hill, Inc., 1980. 633p.

ST. ANGELO, A.J.; ORY, R.L.; BROWN, L.E. Comparison of methods for determining peroxidation in processed whole peanut products. Journal of the American Oil Chemists' Society, v.52, p.34-35, 1975.

TURATTI, J.M.; SALLES, A.M.; SANTOS, L.C.; MORI, E.E.M.; FIGUEIREDO, I.B. Estudos preliminares com cultivares de soja para produção de leite. Boletim do Instituto Tecnológico de Alimentos, v.16, n.3, p.289-305, jul./set. 1979. 
VICK, B.A.; ZIMMERMAN, D.C. Oxidative system for modification of fatty acids: the lipoxigenase pathway. In: STUMPF, P.K.; CONN, E.E., (Ed.) The biochemistry of plants - a comprehensive treatise. Orlando: Academic Press, Inc., 1987. v.9, cap.3, p.53-90.

WANG, H. L.; SWAIN, E. W.; HESSELTINE, C. W.; HEATH, H. D. Hydration of whole soybeans affects solids losses and cooking quality. Journal of Food Science, v.44, p.1510-1513, 1979.

WANG, S.H.; TOLEDO, M.C.F. Inactivation of soybean lipoxygenase by microwave heating: effect of moisture content and exposure time. Journal of Food Science, v. 52, n. 5, p. $1344-1347,1987$.

WANG, S.H; TOLEDO, M.C.F. Evaluacion del valor nutricional de leches de soya preparadas a partir de granos de soya tratados con microondas. Archivos LatinoAmericanos de Nutricion, v.XL, n.4, p.573-587, dez. 1990.

WILKENS, W.F.; MATTICK, L.R.; HAND, D.B. Effect of processing method on oxidative off-flavors of soybean milk. Food Technology, v.21, p.1630-1633, dez. 1967.

WILSON, R.F. Seed metabolism. In: WILCOX, J.R., (Ed.) Soybeans: improvement, production, and uses. $2^{\underline{a}}$ ed. Madison: Academic Press, 1987. cap.16, p.643-686.

WOLF, W.J. Lipoxygenase and flavor of soybean protein products. Journal of Agriculture and Food Chemistry, v.23, n.2, p.136-141, 1975. 
WOLF, W.J. Purification and properties of the proteins. In: SMITH, A.K.; CIRCLE, S.J., (Ed.) Soybeans: chemistry and technology. Westport: AVI Publishing Company, Inc., 1978. v.1, cap.4, p.93-143.

ZANGElMI, A. C. B; TAGLIOLATTO, M. A.; DIAS, E. L.; LANGE, D. A. Produtos de soja - leite, farinha e outros. Secretaria da Indústria, Comércio, Ciência e Tecnologia. s.d., 158p. 